\section{To: (Receiving Organization) \\ Distribution}

5. Proj./Prog./Dept./Div.:

Tank Waste Disposal Division

8. Originator Remarks:

Approve/Release

3. From: (Originating Organization)
Hanford Tanks Initiative
Project
6. Design Authority/ Design Agent/Cog.
Engr.:
D. L. Becker

3. From: (Originating Organization) Hanford Tanks Initiative Project

$$
\text { Engr.: }
$$

D. L. Becker
4. Related EOT No.:

$N / A$

7. Purchase order No.:

TBP-SBC-379954-097

9. Equip./Component No.: $\mathrm{N} / \mathrm{A}$

10. System/Bldg./Facility:

Tank Waste Remediation System

11. Receiver Remarks: 11A. Design Baseline Document? [] Yes [X] No None
$\mathrm{N} / \mathrm{A}$

13. Permit/Permit Application No.: N/A

14. Required Response Date: N/A

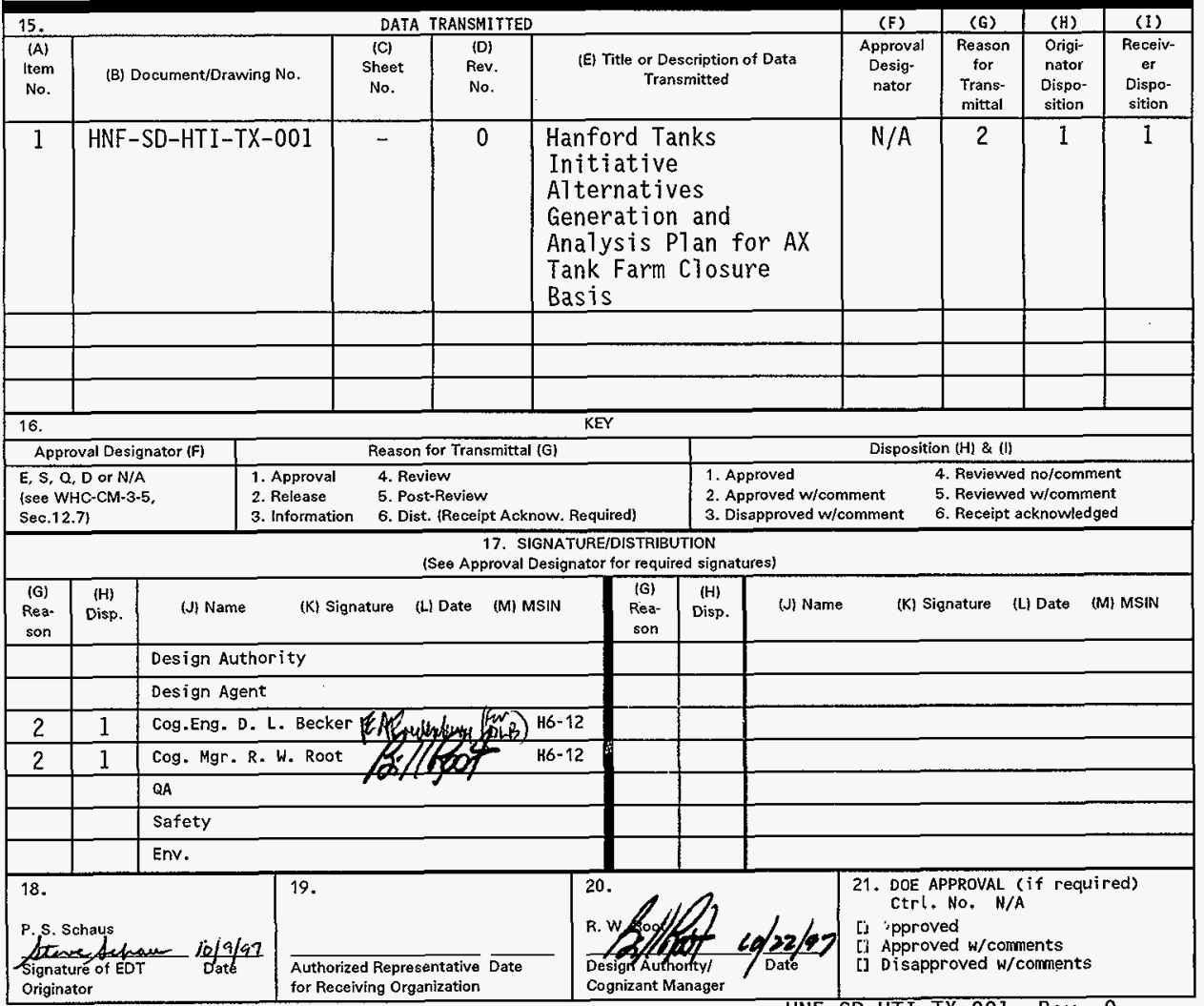




\section{Hanford Tanks Initiative Alternatives Generation and Analysis Plan for AX Tank Farm Closure Basis}

P. S. Schaus and Parsons Infrastructure \& Technology Group, Inc.

Lockheed Martin Hanford Company, Richland, WA 99352

U.S. Department of Energy Contract DE-AC06-96RL13200

EDT/ECN: 622693

Org Code: 73500

B\&R Code: EW3130010
UC: 2030

Charge Code: D26B2

Tota 7 Pages: 75

Key Words: Hanford Tanks Initiative, HTI, single-shell tanks, tank closure, trade studies, alternatives generation and analys is

Abstract: The purpose of this document is: (1) to review the HTI Mission Analysis and related documents to determine their suitability for use in developing performance measures for AX Tank Farm closure, to determine the completeness and representativeness of selected alternative closure scenarios, (3) to determine the completeness of current plans for development of tank end-state criteria, and (4) to analyze the activities that are necessary and sufficient to recommend the end-state criteria and performance measures for the $A X$ Tank Farm and recommend activities not currently planned to support establishment of its end-state criteria.

IRADEMARK DISCLAIMER. Reference herein to any specific comercial product, process, or service by trade name, trademark, manufacturer, or otherwise, does not necessarily constitute or imply its endorsement, recommendation, or favoring by the United States Government or any agency thereof or its contractors or subcontractors.

Printed in the United States of America. To obtain copies of this document, contact: Document Control Services, P.O. Box 950, Mailstop H6-08, Richland WA 99352, Phone (509) 372-2420; Fax (509) 376-4989.
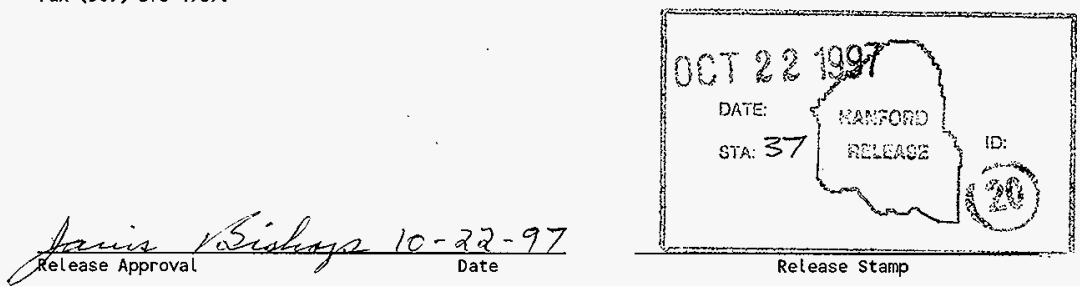
HNF-SD-HTI-TX-001

Revision 0

\title{
HANFORD TANKS INITIATIVE ALTERNATIVES GENERATION \\ AND ANALYSIS PLAN \\ FOR AX TANK FARM \\ CLOSURE BASIS
}

\author{
October 1997 \\ P. S. Schaus \\ Lockheed Martin Hanford Corporation \\ Richland, Washington \\ and \\ Parsons Infrastructure \& Technology Group, Inc. \\ Richland, Washington \\ Prepared for \\ U.S. Department of Energy \\ Richland, Washington
}


HNF-SD-HTI-TX-001

Revision 0

This page intentionally left blank. 
FNF-SD-HTI-TX-001

Revision 0

CONTENTS

1.0 INTRODUCTION AND BACKGROUND $\ldots \ldots \ldots \ldots \ldots \ldots \ldots \ldots$

2.0 DECISION ANALYSIS SUMMARY $\ldots \ldots \ldots \ldots \ldots \ldots \ldots \ldots$

3.0 PROBLEM STATEMENT $\ldots \ldots \ldots \ldots \ldots \ldots \ldots \ldots \ldots$

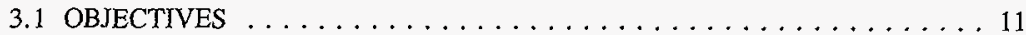

3.2 ISSUES OF CONCERN $\ldots \ldots \ldots \ldots \ldots \ldots \ldots \ldots \ldots \ldots \ldots$

3.3 SCOPE AND LIMITS OF THE PROBLEM $\ldots \ldots \ldots \ldots \ldots \ldots \ldots \ldots 11$

3.4 PERFORMANCE MEASURES $\ldots \ldots \ldots \ldots \ldots \ldots \ldots \ldots \ldots \ldots \ldots$

4.0 CONSTRAINTS AND ASSUMPTIONS $\ldots \ldots \ldots \ldots \ldots \ldots \ldots \ldots \ldots$

4.1 EXTERNAL CONSTRAINTS $\ldots \ldots \ldots \ldots \ldots \ldots \ldots \ldots \ldots \ldots$

4.2 INTERNAL CONSTRAINTS $\ldots \ldots \ldots \ldots \ldots \ldots \ldots \ldots \ldots \ldots \ldots$

4.3 LIMITING ASSUMPTIONS . . . . . . . . . . . . . . . . . 15

4.3.1 Alternatives Screening Assumptions $\ldots \ldots \ldots \ldots \ldots \ldots \ldots$

4.3.2 Stakeholder Involvement . . . . . . . . . . . . . . 16

4.3.3 Subsurface Barrier . . . . . . . . . . . . . . . . . 18

4.4 SIMPLIFYING ASSUMPTIONS $\ldots \ldots \ldots \ldots \ldots \ldots \ldots \ldots$

5.0 ANALYSIS OF PLAN CONTENTS . . . . . . . . . . . . . . . . . . . . . 19

5.1 REVIEW OF HANFORD TANKS INITIATIVE PLAN AND

RELATED DOCUMENTS . . . . . . . . . . . . . . . . 19

5.2 COMPLETENESS OF ALTERNATIVES . . . . . . . . . . . . 19

5.3 COMPLETENESS OF TANK CLOSURE CRITERIA . . . . . . . . . . . 19

5.4 INFORMATION NEEDS . . . . . . . . . . . . . . . . . . 20

5.5 CONTINUING ALTERNATIVES GENERATION AND ANALYSIS

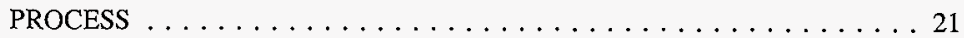

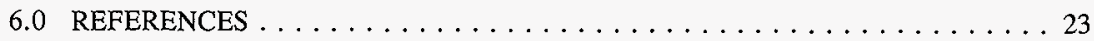

APPENDIXES

A COMPARISON OF INFORMATION NEEDS $\ldots \ldots \ldots \ldots \ldots \ldots$ A-1

B EVALUATION OF INFORMATION NEEDS $\ldots \ldots \ldots \ldots \ldots \ldots$ B-1 


\section{HNF-SD-HTI-TX-001}

Revision 0

\section{LIST OF FIGURES}

1. Alternatives Generation and Analysis Process as Part of the

Hanford Tanks Initiative.

2. Hanford Tanks Initiative Activities to Establish Closure Basis. . . . . . . . . . . . 4

3. Alternatives Generation and Analysis Process. ... . . . . . . . . . . . 5

4. Single-Shell Tank Components. . . . . . . . . . . . . . . . . 9

5. Process for Developing Performance Measure for Closing AX Tank Farm. . . . . . . 10

6. Public Involvement and Risk Management. . . . . . . . . . . . . . . . . 12

\section{LIST OF TABLES}

1. Decision Criteria Matrix. ..................... 8

2. External Constraints. . . . . . . . . . . . . . . . . . . . 14

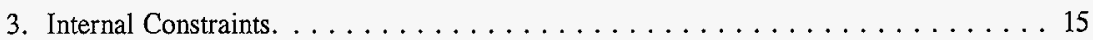

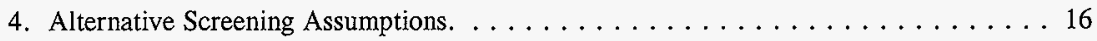

5. Representativeness of the Five Base-Case Alternatives. . . . . . . . . . . . . . 17

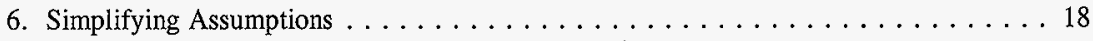

7. Summary of Analysis Provided in Appendix B ... . . . . . . . . . 20 


\section{HINF-SD-HTI-TX-001 \\ Revision 0 \\ LIST OF TERMS}

AGA

CERCLA

CFR

CWP

DOE

DQO

Ecology

EPA

FY

HTI

JEG

MA

MOU

NEPA

NRC

OCRWM

PHMC

RCRA

RPECA

SST

SSSTRS

Tri-Party Agreement

TWRS

WAC

WHC
Alternatives Generation and Analysis

Comprehensive Environmental Response, Compensation, and Liability Act

Code of Federal Regulations

Closure Work Plan

U.S. Department of Energy

Data Quality Objective

Washington State Department of Ecology

U.S. Environmental Protection Agency

Fiscal Year

Hanford Tanks Initiative

Jacobs Engineering Group, Inc.

Mission Analysis

Memorandum of Understanding

National Environmental Policy Act

U.S. Nuclear Regulatory Commission

Office of Civilian Radioactive Waste Management

Project Hanford Management Contractor

Resource Conservation and Recovery Act of 1976

Retrieval Performance Evaluation Criteria Assessment

Single-shell tank

Supplementary single-shell tank retrieval system

Hanford Federal Facility Agreement and Consent Order

Tank Waste Remediation System

Washington Administrative Code

Westinghouse Hanford Company 
HNF-SD-HTI-TX-001

Revision 0

This page intentionally left blank. 
HNF-SD-HTI-TX-001

Revision 0

\section{HANFORD TANKS INITIATIVE ALTERNATIVES GENERATION AND ANALYSIS PLAN FOR AX TANK FARM CLOSURE BASIS}

\subsection{INTRODUCTION AND BACKGROUND}

The Hanford Tanks Initiative (HTI) supports the Hanford Site Single-Shell Tank (SST) Waste Retrieval Program in its commitment to remove waste from the SSTs for treatment and final closure of tanks. A complete understanding of the HTI, its background, and its mission is provided in the Hanford Tanks Initiative Plan, WHC-SD-WM-PMP-022 (WHC 1996a), the Mission Analysis Report for the Hanford Tanks Initiative, WHC-SD-WM-MAR-012 (WHC 1996b), and the Path Forward for Developing Retrieval Performance Evaluation Criteria working paper (FDH 1997). The HTI project will accomplish the following:

- $\quad$ Retrieve the hard-heel waste in SST 241-C-106 and demonstrate alternative technologies to remove waste types from other SSTs.

- Define the process, criteria, and technology to achieve an acceptable end-state for a representative SST Tank Farm (AX Farm).

- Provide a basis, through technology applications, performance assessments, and risk analyses, for establishing an acceptable approach and defining an end-state condition for tank farm closure.

- Conduct residual waste characterization to the extent necessary to support the basis for decisions on retrieval of waste and closure readiness for SST 241-AX-104.

- Obtain the acceptance of regulatory agencies and stakeholders for methods and processes to define completion of tank waste retrieval.

- Develop reliable cost information for various levels of retrieval to support program and regulatory decisions.

The HTI project began in fiscal year (FY) 1996. The HTI will be completed before FY 2002, at which time the preparation of the request for proposals for Phase II privatization (tank retrieval) will be completed.

The products of this plan are as follows:

1. Review the HTI Plan Mission Analysis (MA) and related documents to determine their suitability for use in development of performance measures for AX Tank Farm closure. 
HNF-SD-HTI-TX-001

Revision 0

2. Determine completeness and representativeness of selected alternative closure scenarios.

3. Determine completeness of current plans for development of tank end-state criteria.

4. Perform an analysis of the activities that are necessary and sufficient to recommend the end-state criteria and performance measures for a representative SST farm (AX Tank Farm) and recommend activities not currently planned to support establishment of end-state criteria for AX Tank Farm.

The closure basis for AX Tank Farm will evaluate end-state alternatives for tanks, surrounding soil, ancillary equipment and surface barriers. The process developed in recommending a closure basis for AX Tank Farm may be a prototype for closure of future tank farms.

The Hanford Federal Facility Agreement and Consent Order (also known as the TriParty Agreement) (Ecology et al. 1994) Milestone M-45 states, "Final closure of the operable units (Tank Farms) shall be defined as regulatory approval of completion of closure actions and commencement of post-closure actions. For the purposes of this agreement, all units located within the boundary of each tank farm will be closed in accordance with WAC 173-303-610. This includes contaminated soil and ancillary equipment that were previously designated as Resource Conservation and Recovery Act of 1976 (RCRA) PastPractice Units." The Washington State Department of Ecology (Ecology) is the lead regulatory agency for tank farm operable unit closure.

This document provides the planning to ensure all information will be available to support a recommendation on AX Tank Farm closure basis. Figure 1 depicts how the Alternatives Generation and Analysis (AGA) process interfaces with HTI. Where information is unknown, trade studies are recommended to develop that information.

Figure 2 depicts the key activities involved in recommending a closure basis for AX Tank Farm and the interfaces between HTI and TWRS retrieval and closure activities. 
HNF-SD-HTI-TX-001

\section{Revision 0}

Figure 1. Alternatives Generation and Analysis Process as Part of the Hanford Tanks Initiative.

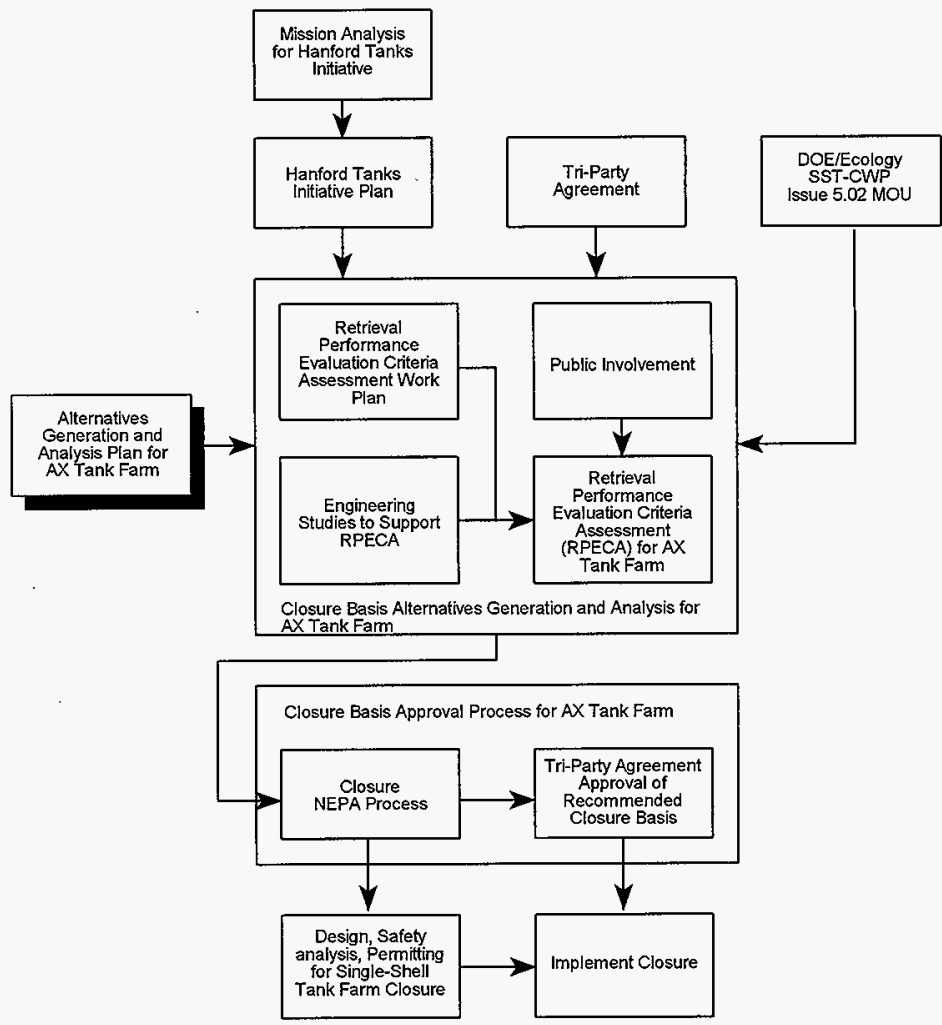

CWP $=$ Closure Work Plan

DOE = U.S. Department of Energy

MOU $=$ Memorandum of Understanding

NEPA = National Environmental Policy Act of 1969

SST $=$ Single-shell tank. 


\section{HNF-SD-HTI-TX-001}

Revision 0

Figure 2. Hanford Tanks Initiative Activities to Establish Closure Basis.

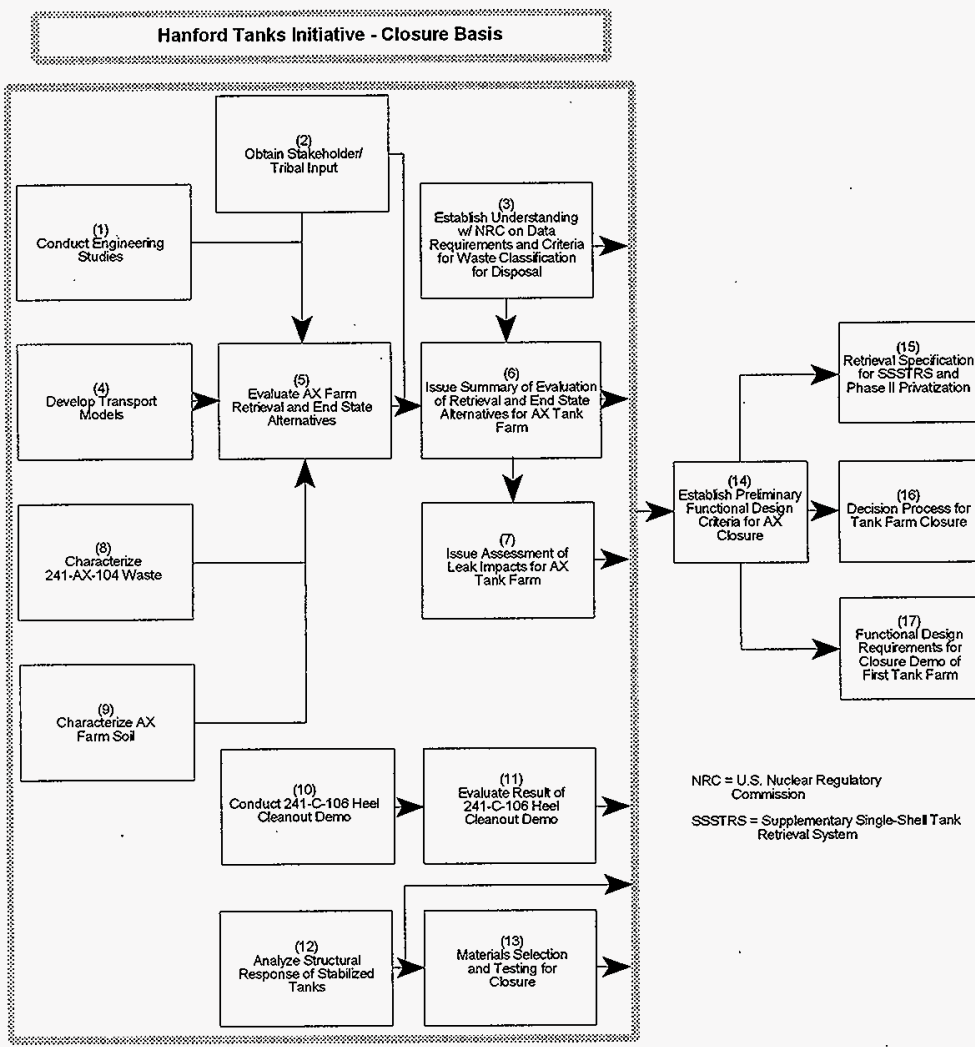


HNF-SD-HTI-TX-001

Revision 0

\subsection{DECISION ANALYSIS SUMMARY}

Figure 3 illustrates the AGA process as it will be applied to the development of the AX Tank Farm closure basis. The AGA process is described in the TWRS Systems Engineering Manual, WHC-IP-1231, Section 3.0, "Alternatives Generation and Analysis" (WHC 1996c).

Figure 3. Alternatives Generation and Analysis Process.

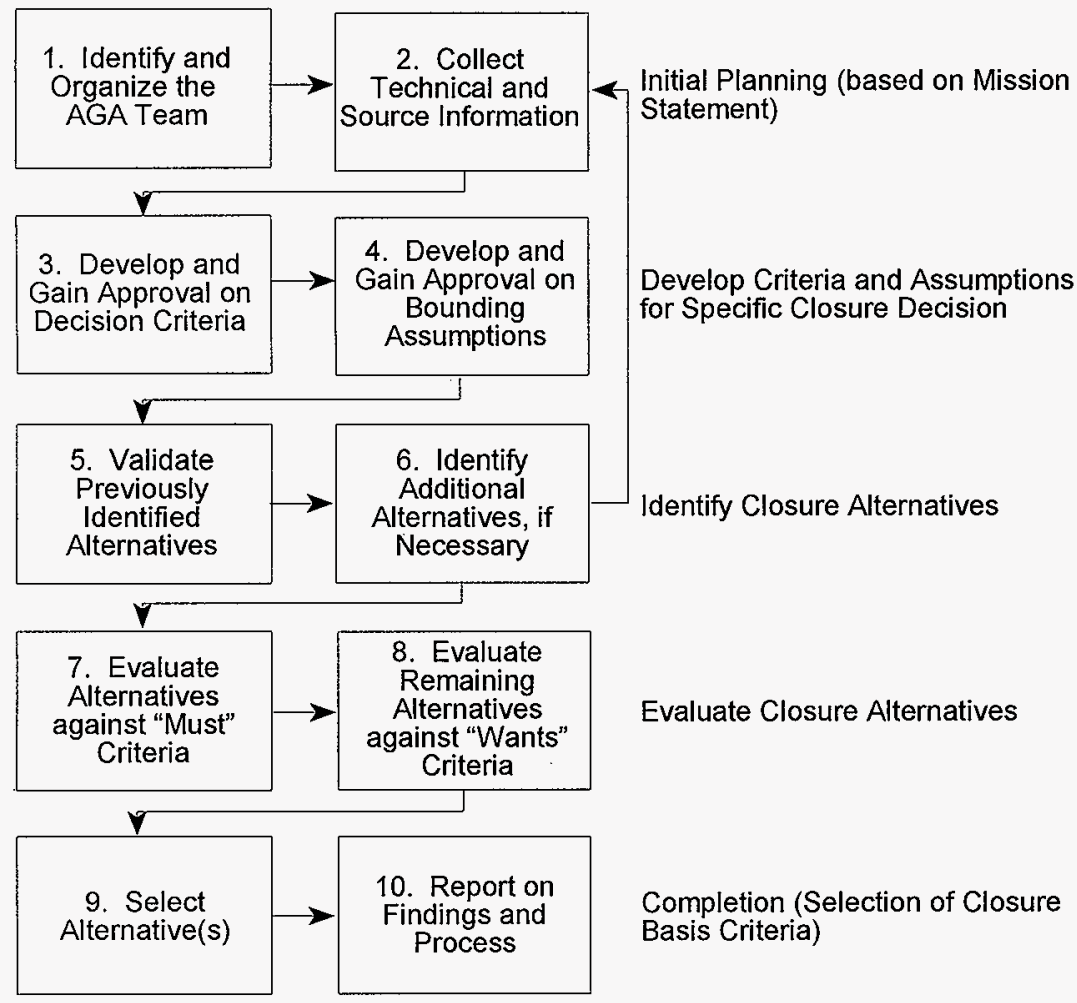




\section{Revision 0}

The process used to determine the AGA studies necessary and sufficient to establish the closure basis is documented in Appendix A, Comparison of Information Needs, and Appendix B, Evaluation of Information Needs. The process is summarized in the following items.

1. The HTI mission was analyzed to determine the Closure Basis Decisions that must be made to establish a recommendation for the AX Tank Farm closure basis. The Closure Basis Decisions that have been developed are as follows:

- What amount and classification of residual waste is allowed to remain?

- What amount of waste leakage is allowable during retrieval?

- What type of treatment is needed for residual waste, if any?

- Is retrieval of SST shell and structural material necessary?

- Is ancillary equipment retrieval and treatment necessary; if so, what treatment will be performed?

- Is in-tank equipment removal and treatment necessary; if so, what treatment will be performed?

- What type of soil remediation will be performed, if any?

- What type of vadose zone remediation will be performed, if any?

- What surface barriers will be used, if any?

- What subsurface barriers will be used, if any?

- What in-tank subsidence prevention will be used, if any?

- How do treatment process system effects affect the other Closure Basis Decisions?

2. For each Closure Basis Decision, Decision Criteria were developed, based on internal and external requirements that will influence the Closure Basis Decisions. The Decision Criteria that apply to each Closure Basis Decision are indicated in Table 1. The Decision Criteria formulated are as follows:

- Does it meet Tri-Party Agreement requirements?

- Does it meet regulatory requirements? 
HNF-SD-HTI-TX-001

Revision 0

- Does residual meet U.S. Nuclear Regulatory Commission (NRC) requirements as incidental waste or must the radioactive constituents in the residual waste be disposed of as high-level waste?

- Does it satisfy public concerns and values?

- Does it provides for public safety?

- Does it provide for worker safety?

- Does it protect the environment?

3. For each Closure Basis Decision, the information to satisfy the Decision Criteria was developed. From this process, information development activities could be linked to each Closure Basis Decision.

4. All similar information development activities were grouped into information gathering activities in Appendix B. The necessary information gathering activities were compared to planned and existing studies to determine the information needs that are not being satisfied under current plans. The scope of planned studies was compared to the necessary information development activities to determine if any planned work was not necessary to establish the closure basis. 
Table 1. Decision Criteria Matrix.

\begin{tabular}{|c|c|c|c|c|c|c|c|}
\hline \multirow[b]{2}{*}{ Closure Basis Decisions } & \multicolumn{7}{|c|}{ Decision Criteria } \\
\hline & $\begin{array}{l}\text { Does it meet } \\
\text { Tri-Party } \\
\text { Agreement } \\
\text { requirements }\end{array}$ & $\begin{array}{l}\text { Complies with } \\
\text { regulatory } \\
\text { requirements? }\end{array}$ & $\begin{array}{l}\text { Does residual } \\
\text { meet NRC } \\
\text { requirements as } \\
\text { incidental waste? }\end{array}$ & $\begin{array}{c}\text { Satisfies } \\
\text { public } \\
\text { concerns and } \\
\text { values }\end{array}$ & $\begin{array}{l}\text { Provides } \\
\text { for public } \\
\text { safety }\end{array}$ & $\begin{array}{l}\text { Provides for } \\
\text { worker } \\
\text { safety? }\end{array}$ & $\begin{array}{l}\text { Protects the } \\
\text { environment? }\end{array}$ \\
\hline $\begin{array}{l}\text { Arnount and classification of } \\
\text { residual waste allowed to } \\
\text { remain }\end{array}$ & $\mathrm{x}$ & $\mathrm{x}$ & $\mathrm{x}$ & $\mathrm{x}$ & $\mathrm{X}$ & $\mathrm{x}$ & $\mathrm{X}$ \\
\hline $\begin{array}{l}\text { Amount of waste leakage } \\
\text { allowable during retrieval }\end{array}$ & $x$ & $x$ & & $x$ & $\mathrm{X}$ & $\mathrm{X}$ & $\mathrm{x}$ \\
\hline Treatment of residual waste & & $\mathrm{X}$ & $\mathrm{X}$ & $\mathrm{X}$ & $\mathrm{x}$ & $\mathrm{x}$ & $\mathrm{x}$ \\
\hline $\begin{array}{l}\text { Retrieval of single-shell tank } \\
\text { shell and structural material }\end{array}$ & & $\mathrm{X}$ & & $\mathrm{x}$ & $\mathrm{X}$ & $\mathrm{X}$ & $\mathrm{X}$ \\
\hline $\begin{array}{l}\text { Ancillary equipment retrieval } \\
\text { and treatment }\end{array}$ & & $\mathrm{x}$ & $\mathrm{X}$ & $\mathrm{X}$ & $\mathrm{x}$ & $\mathrm{x}$ & $\mathrm{x}$ \\
\hline $\begin{array}{l}\text { In-tank equipment removal and } \\
\text { treatment }\end{array}$ & & $\mathrm{x}$ & & $x$ & $\mathrm{x}$ & $\mathrm{X}$ & $\mathrm{x}$ \\
\hline Soil remediation & & $x$ & $\mathrm{X}$ & $\mathrm{X}$ & $\mathrm{X}$ & $\mathrm{X}$ & $\mathrm{x}$ \\
\hline Vadose zone remediation & & $\mathrm{X}$ & & $\mathrm{x}$ & $\mathrm{X}$ & $\mathrm{x}$ & $\mathrm{x}$ \\
\hline Surface barriers & & $\mathrm{X}$ & & $\mathrm{x}$ & $\mathrm{X}$ & $\mathrm{X}$ & $\mathrm{x}$ \\
\hline Subsurface barriers & & $\mathrm{x}$ & & $\mathrm{x}$ & $\mathrm{X}$ & $\mathrm{X}$ & $\mathrm{X}$ \\
\hline Subsidence prevention & & $\mathrm{X}$ & & $x$ & $\mathrm{X}$ & $\mathrm{x}$ & $\mathrm{X}$ \\
\hline $\begin{array}{l}\text { Treatment process system } \\
\text { effects }\end{array}$ & & $\mathrm{X}$ & & $\mathrm{x}$ & $\mathrm{x}$ & $\mathrm{x}$ & $\mathrm{X}$ \\
\hline
\end{tabular}

NRC = U.S. Nuclear Regulatory Commission. 
HNF-SD-HTI-TX-001

Revision 0

\subsection{PROBLEM STATEMENT}

An AGA provides a logical and systematic process for developing a conclusion based on available and developed technical information. This AGA plan describes both AGA studies and technical background development activities necessary to address all aspects of the closure basis for the AX Tank Farm.

The AX Tank Farm consists of many components, as illustrated in Figure 4. Decisions regarding the final condition of each component will be the result of the systematic AGA process, based on decision criteria.

Figure 4. Single-Shell Tank Components.

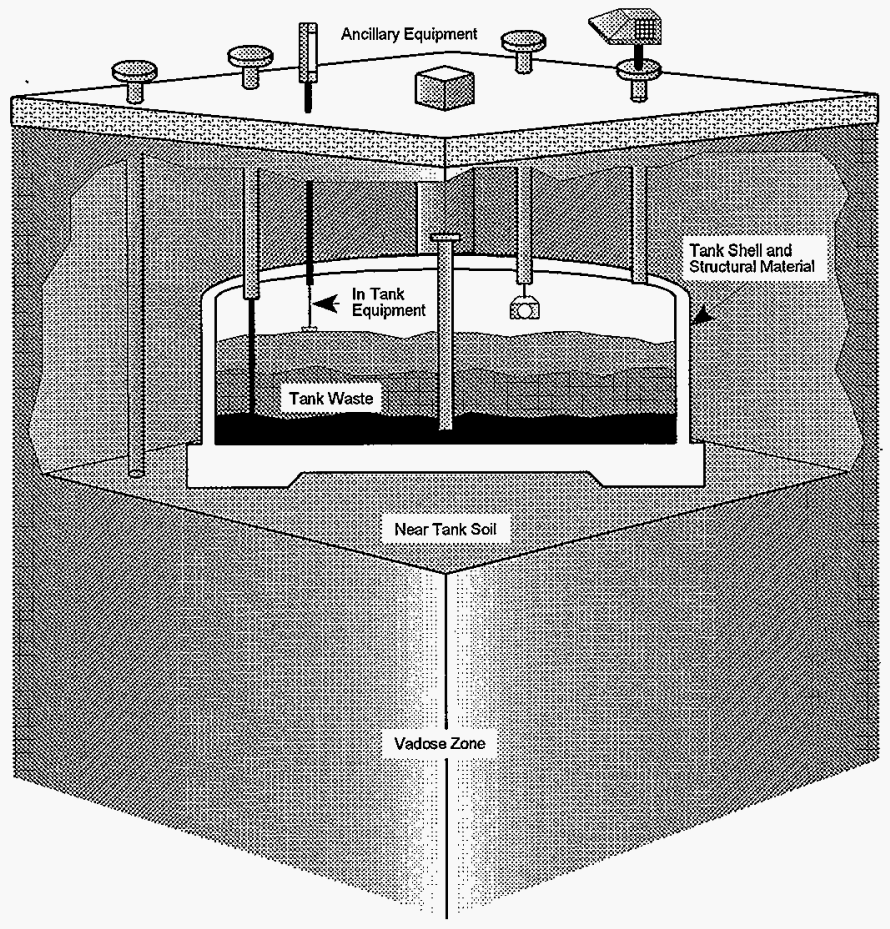




\section{HNF-SD-HTI-TX-001 \\ Revision 0}

Figure 5 indicates that most of the work to be accomplished by HTI is information development, evaluation, and analyses to support public/stakeholder involvement and development of recommendations for final performance measures (criteria) for closure basis.

Figure 5. Process for Developing Performance Measure for Closing AX Tank Farm.
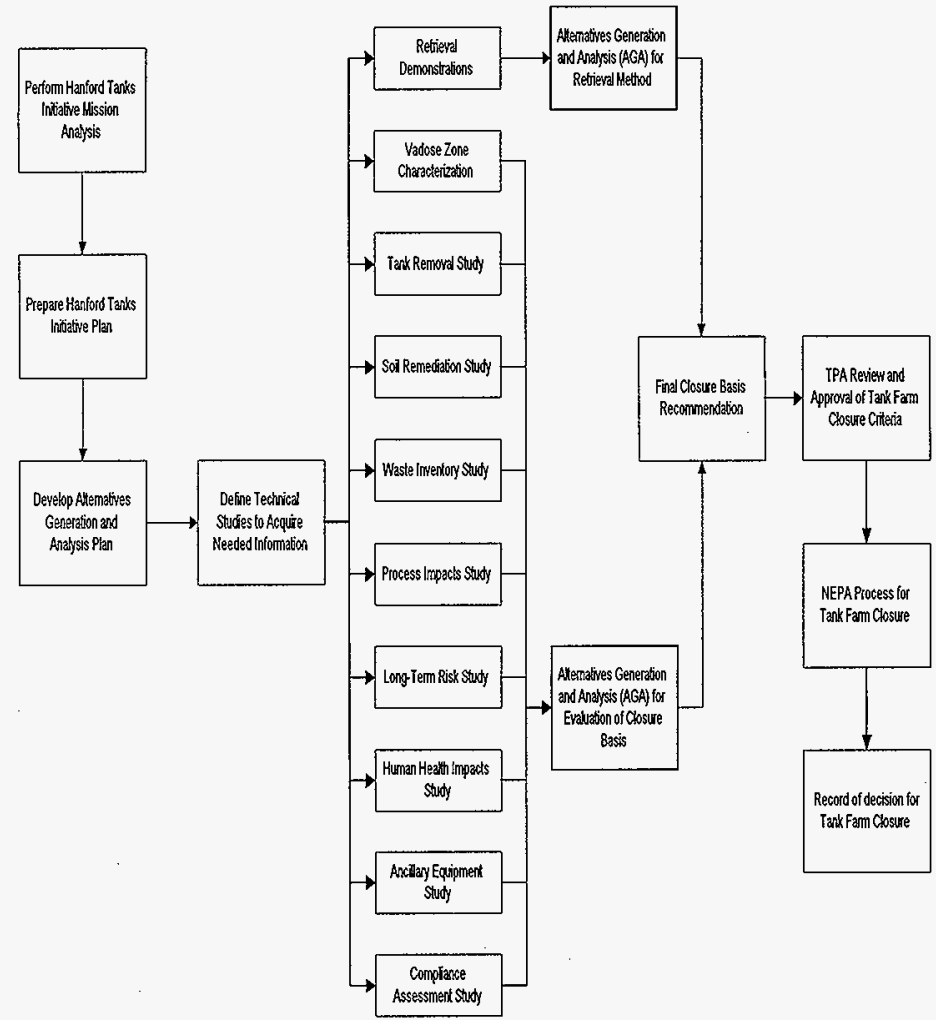

$\mathrm{NEPA}=$ National Environmental Policy Act of 1969. 


\subsection{OBJECTIVES}

The objective of this AGA plan is to identify a process to develop recommendations for end-state criteria for the closure basis for the AX Tank Farm in a manner that is safe for workers and the public, environmentally sound, and cost effective. The closure basis must be acceptable to the parties of the Tri-Party Agreement, the public, and other stakeholders. To achieve the desired product, a thorough assessment of risks to human health and the environment and cost will be completed for each alternative examined.

An alternative for closing the AX Tank Farm is a scenario that describes the combined end-states of each tank farm "component" and the process for achieving that end-state, as described in Section 2.0.

\subsection{ISSUES OF CONCERN}

The key issues of concern addressed in this plan are as follows:

1. The processes and costs of acquiring necessary and sufficient data for setting acceptable performance measures for a first-of-a-kind operation

2. Conducting, in a timely manner, an adequate public/stakeholder involvement program to achieve acceptance of recommended measures

3. Selecting and analyzing sufficient alternatives to bound all viable closure alternatives

4. Obtaining a finding from NRC that residual tank wastes can be classified as "incidental" wastes, and therefore, to be disposed of under DOE regulation

5. Limits of technical capability for waste retrieval.

\subsection{SCOPE AND LIMITS OF THE PROBLEM}

The scope of this plan is to identify those activities required to obtain the necessary and sufficient information to develop recommendations of end-state criteria for closing AX Tank Farm. No other tank farm is being addressed by this plan, although the results of the AGAs discussed in this plan may provide input into decisions regarding other tank farms.

A comprehensive and continuous public/stakeholder involvement process is a major component of this plan and is a major factor in the Tri-Party Agreement decision process (JEG 1997a and DOE et al. 1996). This planning portion of the scope and the interplay of the public/stakeholder involvement process is shown in Figure 6. 


\section{HNF-SD-HTI-TX-001}

\section{Revision 0}

Figure 6. Public Involvement and Risk Management.

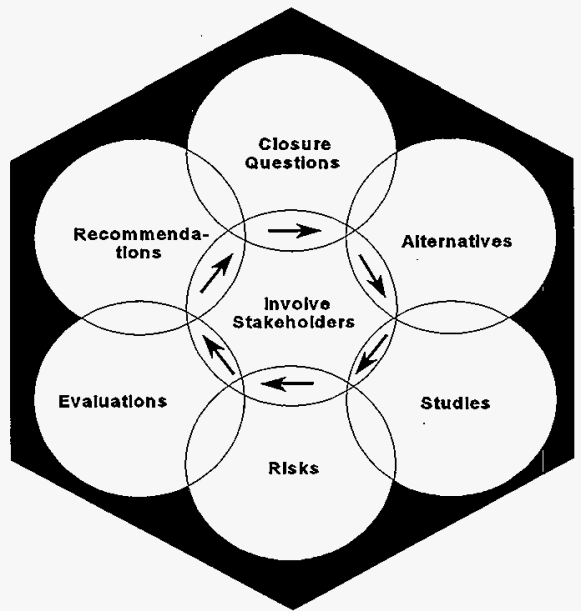

\subsection{PERFORMANCE MEASURES}

Performance measures (criteria) will be quantitative expressions that answer key closure basis questions (decisions). This plan delineates the information needs, the decision criteria, the studies that will develop the information, and the AGAs that will lead to recommendations for the end-state for AX Tank Farm. The closure basis criteria and related decision criteria and information needs are provided in Appendices A and B. 
HNF-SD-HTI-TX-001

Revision 0

\subsection{CONSTRAINTS AND ASSUMPTIONS}

Achieving agreement on the set of end-state performance measure (criterion) recommendations of AX Tank Farm will be a systematic and interactive process involving multiple internal and external interfaces. The process will involve the Project Hanford Management Contractor (PHMC), subcontractors, U.S. Department of Energy (DOE), U.S. Environmental Protection Agency (EPA), Ecology, the public, and stakeholders in an ongoing, open-involvement process. This plan summarizes the need for, and development of, technical information to be used in this process. The technical information needs were defined through the process illustrated in Figure 5 (see Section 3.3). The constraints and assumptions guiding and limiting the overall process of establishing a closure basis for AX Tank Farm are delineated in the following sections.

\subsection{EXTERNAL CONSTRAINTS}

External constraints on closure of the AX Tank Farm are those constraints imposed by other than PHMC and DOE as shown in Table 2. 
Revision 0

Table 2. External Constraints.

\begin{tabular}{|c|c|c|}
\hline Item & External constraint source & Description \\
\hline 1 & Tri-Party Agreement & $\begin{array}{l}\text { M-45-00 Milestone requirements. } \\
\text { Schedule Requirements } \\
\text { Remaining Tank Waste Volume } \\
\text { Technical Achievability } \\
\text { May Consider Cost Factors and Worker Exposure } \\
\text { Public/Stakeholder Involvement - Must develop and } \\
\text { implement an approved plan. } \\
\text { Interface with other related milestones. }\end{array}$ \\
\hline 2 & Ecology & $\begin{array}{l}\text { Washington State Environmental Requirements, } \\
\text { WAC } 173 \text { and State Environmental Policy Act } \\
\text { requirements. }\end{array}$ \\
\hline 3 & $\begin{array}{l}\text { Washington State } \\
\text { Department of Health }\end{array}$ & Radiation Air Emissions Program, WAC 246-247 \\
\hline 4 & $\begin{array}{l}\text { Nuclear Regulatory } \\
\text { Commission }\end{array}$ & $\begin{array}{l}\text { Regulatory Requirements - Classification of Residual } \\
\text { Wastes. }\end{array}$ \\
\hline 5 & $\begin{array}{l}\text { Council on Environmental } \\
\text { Quality }\end{array}$ & $\begin{array}{l}\text { National Environmental Policy Act (NEPA), } \\
40 \text { CFR } 1500-1508\end{array}$ \\
\hline 6 & EPA & $\begin{array}{l}\text { National Emission Standards for Hazardous Air } \\
\text { Poliutants, } 40 \text { CFR } 61 \text {; } \\
\text { National Pollutant Discharge Elimination System, } \\
40 \text { CFR 122-136; and } \\
\text { Environmental Radiation Protection Standards for } \\
\text { Management and Disposal of Spent Nuclear Fuel, } \\
\text { High-Level and Transuranic Radioactive Wastes, } \\
40 \text { CFR } 191\end{array}$ \\
\hline
\end{tabular}

CFR $=$ Code of Federal Regulations

Ecology = Washington State Department of Ecology

$\mathrm{EPA}=$ U.S. Environmental Protection Agency

RCRA = Resource Conservation and Recovery Act of 1976.

$\mathrm{WAC}=$ Washington Administrative Code.

\subsection{INTERNAL CONSTRAINTS}

Internal constraints and assumption are those imposed by DOE or the PHMC contractors and are shown in the following Table 3. 
HNF-SD-HTI-TX-001

Revision 0

Table 3. Internal Constraints.

\begin{tabular}{|c|c|c|}
\hline Item & Internal constraints & Description \\
\hline 1 & $\begin{array}{l}\text { DOE Waste Management } \\
\text { Requirements }\end{array}$ & DOE Order $5820.2 \mathrm{~A}$ Waste management \\
\hline 2 & $\begin{array}{l}\text { DOE Worker Exposure Control } \\
\text { Requirements }\end{array}$ & $\begin{array}{l}10 \text { CFR } 835 \text { Occupational Radiation } \\
\text { Protection }\end{array}$ \\
\hline 3 & $\begin{array}{l}\text { DOE Environmental Protection } \\
\text { Requirements }\end{array}$ & DOE Order 5400 Environmental Protection. \\
\hline 4 & $\begin{array}{l}\text { DOE Public Protection } \\
\text { Requirements }\end{array}$ & $\begin{array}{l}\text { DOE Order } 5400.5 \text { Radiation Protection of } \\
\text { the Public. }\end{array}$ \\
\hline 5 & $\begin{array}{l}\text { DOE National Environmental Policy } \\
\text { Act Requirements }\end{array}$ & 10 CFR 1021 NEPA Implementation. \\
\hline 6 & Quality Management & $\begin{array}{l}10 \text { CFR } 830.120 \text { Nuclear Quality } \\
\text { Management }\end{array}$ \\
\hline 7 & Life-Cycle Management & 10 CFR 430.1 Life-Cycle Asset Management \\
\hline
\end{tabular}

\subsection{LIMITING ASSUMPTIONS}

The problem statement is so large for this AGA plan that initial screening and aggregation of the alternatives were required to select a reasonable number of alternatives to represent the possibilities in the early stage of recommendation making.

\subsubsection{Alternatives Screening Assumptions}

Several assumptions were made to allow for the alternatives screening process. Testing of these assumptions will continue at the alternatives recommendation points of the various planned studies. Testing must ensure that the selections are viable under the assumptions and that further screening, aggregation, evaluation, and recommendations can continue for the next step. Assumptions used for the initial screening for representative alternatives are provided in Table 4. 
HNF-SD-HTI-TX-001

Revision 0

Table 4. Alternative Screening Assumptions.

\begin{tabular}{|c|l|l|}
\hline Item & \multicolumn{1}{|c|}{ Alternatives Screening Action } & \multicolumn{1}{c|}{ Assumptions } \\
\hline 1 & $\begin{array}{l}\text { Identify all alternatives within the } \\
\text { limits of the Tank Waste } \\
\text { Remediation Systems Environmental } \\
\text { Impact Statement Record of } \\
\text { Decision }\end{array}$ & $\begin{array}{l}\text { a. Some level of retrieval required. } \\
\text { b. Surface barriers required except for clean } \\
\text { closure (55 alternatives identified). }\end{array}$ \\
\hline 2 & Develop Base Case Alternatives & $\begin{array}{l}\text { a. Eliminate alternatives that leave all waste } \\
\text { in the tank farm. } \\
\text { b. Develop base case alternatives using best- } \\
\text { estimate calculations and commonly accepted } \\
\text { mitigation measures (five identified). }\end{array}$ \\
\hline 3 & & $\begin{array}{l}\text { Assumed variables considered: } \\
\text {-Retrieval Waste Leakage } \\
\text { Identify Alternative Component } \\
\text { Variable Cases }\end{array}$ \\
& & $\begin{array}{l}\text {-Surface Barrier, temporary barrier. } \\
\text {-Soil Remediation } \\
\text {-Residual Waste Allowed to Remain } \\
\text {-Tank Shell and Structure Removal }\end{array}$ \\
\hline
\end{tabular}

The result of this screening process was the selection of five base-case alternative closure scenarios. These five scenarios were evaluated against the closure basis decisions, as shown in Table 5 (JEG 1997b,c). Table 5 shows that the base case scenarios are complete and representative for the range of variables considered. The other variables; treatment of residual waste, ancillary equipment treatment and retrieval, in-tank equipment removal and treatment, Vadose zone remediation, and treatment process system effects are being studied separately so that the results can be applied to all base case alternatives.

\subsubsection{Stakeholder Involvement}

Stakeholder involvement will be included in all steps of the AGA process. The key to the success of this process is to ensure that all public and stakeholder values are considered and expressed quantitatively in the derived performance measures (criteria). The process assumed for this plan is shown in Figure 6 (see Section 3.3). 
Table 5. Representativeness of the Five Base-Case Alternatives.

\begin{tabular}{|c|c|c|c|c|c|c|c|c|c|c|c|}
\hline \multirow{2}{*}{$\begin{array}{l}\text { Closure } \\
\text { Base- } \\
\text { Case } \\
\text { Alterna- } \\
\text { tives }\end{array}$} & \multicolumn{11}{|c|}{ Closure Basis Decisions } \\
\hline & $\begin{array}{c}\text { Amount and } \\
\text { classification } \\
\text { of residual } \\
\text { waste allowed } \\
\text { to remain }\end{array}$ & $\begin{array}{l}\text { Amount of } \\
\text { waste } \\
\text { leakage } \\
\text { allowed } \\
\text { during } \\
\text { retrieval }\end{array}$ & $\begin{array}{c}\text { Treat- } \\
\text { ment of } \\
\text { residual } \\
\text { waste }\end{array}$ & $\begin{array}{l}\text { Retrieval } \\
\text { of shell } \\
\text { and } \\
\text { structural } \\
\text { material }\end{array}$ & $\begin{array}{l}\text { Ancillary } \\
\text { equipment } \\
\text { retrieval } \\
\text { and } \\
\text { treatment }\end{array}$ & $\begin{array}{l}\text { In-tank } \\
\text { equipment } \\
\text { removal } \\
\text { and } \\
\text { treatment }\end{array}$ & $\begin{array}{l}\text { Soil } \\
\text { remedia- } \\
\text { tion }\end{array}$ & $\begin{array}{l}\text { Vadose } \\
\text { zone } \\
\text { remedia- } \\
\text { tion }\end{array}$ & $\begin{array}{l}\text { Surface } \\
\text { barriers }\end{array}$ & $\begin{array}{l}\text { Subsidence } \\
\text { prevention }\end{array}$ & $\begin{array}{c}\text { Treatment } \\
\text { process } \\
\text { system } \\
\text { effects }\end{array}$ \\
\hline 1 & $\begin{array}{c}36,360 \text { and } \\
3,600 \mathrm{ft}^{3}\end{array}$ & $\begin{array}{l}8,000 \text { and } \\
40,000 \text { gal }\end{array}$ & note 1 & no & note 1 & note 1 & none & note 1 & $\begin{array}{l}\text { Temp. } \\
\text { Asphalt, } \\
\text { RCRA } \\
\text { Cap, or } \\
\text { Hanford } \\
\text { Barrier }\end{array}$ & note 2 & note 1 \\
\hline 2 & $360 \mathrm{ft}^{3}$ & $\begin{array}{l}8,000 \text { and } \\
40,000 \text { gal }\end{array}$ & note 1 . & no & note 1 & note 1 . & in situ & note 1 & $\begin{array}{c}\text { RCRA } \\
\text { Cap } \\
\end{array}$ & note 2 & note 1 \\
\hline 3 & $360 \mathrm{ft}^{3}$ & $\begin{array}{c}0 \text { and } \\
8,000 \mathrm{gal}\end{array}$ & NA & yes & note 1 & note 1 & excavate & note 1 & none & $\mathrm{n} / \mathrm{a}$ & note 1 \\
\hline 4 & $360 \mathrm{ft}^{3}$ & $\begin{array}{c}0 \text { and } \\
8,000 \mathrm{gal}\end{array}$ & NA & yes & note 1 & note 1 & in situ & note 1 & none & $\mathrm{n} / \mathrm{a}$ & note 1 \\
\hline 5 & $360 \mathrm{ft}^{3}$ & $8,000 \mathrm{gal}$ & NA & yes & note 1 & note 1 & none & note 1 & $\begin{array}{c}\text { RCRA } \\
\text { Cap } \\
\end{array}$ & $\mathrm{n} / \mathrm{a}$ & note 1 \\
\hline
\end{tabular}

RCRA $=$ Resource Conservation and Recovery Act of 1976

Notes: 1. Not specifically addressed in the base case alternatives.

2. For all cases where the tanks are left in the ground (landfill cases) subsidance prevention is included in the alternative.

Alternative 1 Retrieve waste to the Tri-Party Agreement limit $\left(360 \mathrm{ft}^{3}\right)$, and close the tank farm as a landfill with no tank removal or soil remediation, a nominal amount of retrieval leakage $(8,000 \mathrm{gal})$, stabilize tanks, and construct a RCRA equivalent cap.

Sub Alternatives:

a) Maximum retrieval leakage of $40,000 \mathrm{gal}$

b) Residual waste volumes of $36 \mathrm{ft}^{3}$ and $3,600 \mathrm{ft}^{3}$

c) Temporary surface barrier prior to retrieval

d) Hanford surface barrier instead of RCRA equivalent cap after retrieval.

Alternative 2 Retrieve waste to the Tri-Party Agreement limit and close the tank farm as a landfill with no tank removal, but with in-place soil remediation, a nominal amount of retrieval leakage $(8,000$ and 40,000 gal), in situ soil remediation, stabilize tanks, and construct a RCRA equivalent cap.

Alternative 3 Retrieve waste to the Tri-Party Agreement limit, remove tanks, nominal leakage during retrieval, excavate contaminated soil and dispose of contaminated soil in an onsite engineered disposal facility, and do not use a surface barrier.

Alternative 4 Retrieve waste to the Tri-Party Agreement limit, remove tanks, nominal leakage during retrieval, in situ soil remediation, no surface barrier.

Alternative 5 Retrieve waste to the Tri-Party Agreement limit, remove tanks, nominal leakage during retrieval, no soil remediation, install RCRA equivalent barrier. 


\subsubsection{Subsurface Barrier}

Based on recent evaluations and recommendations, it has been decided that a barrier under the AX Tanks will not be considered because of poor cost/benefit (WHC 1995 and Ecology et al. 1995).

\subsection{SIMPLIFYING ASSUMPTIONS}

Simplifying assumptions have been employed, where deemed appropriate, to maintain the AX Tank Farm Closure Basis development on a cost-effective footing. These assumptions are being used to design and conduct studies for base-case alternatives to minimize the number of studies and quantity of information necessary to evaluate alternatives and create quality performance measure recommendations. Current simplifying assumptions used in the process are listed in Table 6.

Table 6. Simplifying Assumptions.

\begin{tabular}{|c|l|l|}
\hline Item & \multicolumn{1}{|c|}{ Process action } & \multicolumn{1}{c|}{ Current simplifying assumption } \\
\hline 1 & Residual Waste Category & $\begin{array}{l}\text { U.S. Nuclear Regulatory Commission will } \\
\text { designate as incidental waste. }\end{array}$ \\
\hline 2 & Soil Excavation & Will be acceptable for onsite disposal. \\
\hline 3 & Surface Barrier & $\begin{array}{l}\text { A RCRA equivalent surface barrier will be } \\
\text { sufficient. }\end{array}$ \\
\hline 4 & Retrieval Evaluations & $\begin{array}{l}\text { Will meet the minimum standard stated in the } \\
\text { Tri-Party Agreement. }\end{array}$ \\
\hline
\end{tabular}

RCRA $=$ Resource Conservation and Recovery Act of 1976. 
HNF-SD-HTI-TX-001

Revision 0

\subsection{ANALYSIS OF PLAN CONTENTS}

This plan has been evaluated for consistency with the HTI Project and related plans and documents to determine if the planned and on-going studies will provide the necessary and sufficient information to develop recommendations for end-state performance measures for AX Tank Farm. Planned and ongoing studies were determined from the Single-Shell Tank Closure Work Plan (DOE-RL 1996), and the Retrieval Performance Evaluation Criteria Assessment Work Plan (JEG 1997d). Sections 5.1 through 5.4 provide the evaluation of the four key purposes for developing this plan. Section 5.5 provides the continuing AGA process.

\subsection{REVIEW OF HANFORD TANKS INITIATIVE PLAN AND RELATED DOCUMENTS}

The HTI Mission Analysis, HTI Plan, Draft SST Closure Plan, and other documents describing the scopes and status of various planned and ongoing studies were reviewed. These related documents define the decisions to be made and the information necessary and sufficient to make those decisions so that AX Tank Farm can be placed in an end-state condition in a safe and environmentally acceptable manner. This process was described in Figure 5 (see Section 3.3).

The documents reviewed provided the information necessary to evaluate the plans and process for developing recommendations for performance measures for AX Tank Farm endstate condition.

\subsection{COMPLETENESS OF ALTERNATIVES}

The method for selecting the five alternative scenarios for analyzing risks of closing $\mathrm{AX}$ Tank Farm was evaluated and described in Section 4.3. This method was deemed to be adequate in that all information needed to address the decision criteria are addressed as shown in Table 5 (see Section 4.3.1).

\subsection{COMPLETENESS OF TANK CLOSURE CRITERIA}

The closure criteria, as listed in the first column of the tables in Appendix B, have been reviewed and determined to be necessary and sufficient for developing performance measures for closing AX Tank Farm. As shown in Appendix B, the closure basis criteria, decision criteria, information needs, and planned studies demonstrate a complete system of elements that address all of the safety and environmental issues associated with the tanks and their environs, including the processing and management of waste, tank components, ancillary equipment, and soils around and below the tanks. 


\section{Revision 0}

\subsection{INFORMATION NEEDS}

The 12 closure basis decisions are each analyzed on an individual table in Appendix A. A detailed gap analysis was performed and the results are provided in Appendix B. There are 16 tables in Appendix B, one for each required information-gathering activity. Tables 7 and 8 provide a summary of the evaluation in Appendix B. Studies that require a re-examination of scope (Categories 2, 3, and 4) are listed in Table 8.

Table 7. Summary of Analysis Provided in Appendix B.

\begin{tabular}{|c|l|c|}
\hline Category & \multicolumn{1}{|c|}{ Category description } & Number \\
\hline 1 & Currently Planned, no change in scope, no comments & 12 \\
\hline 2 & Currently Planned, no change in scope, comments & 1 \\
\hline 3 & Currently planned, scope needs modifying & 1 \\
\hline 4 & Not currently planned, new scope, no comments & 1 \\
\hline
\end{tabular}

Table 8. Evaluation Summary of Information Needs.

\begin{tabular}{|l|c|l|}
\hline \multicolumn{1}{|c|}{ Study } & Category & \multicolumn{1}{c|}{ Scope changes needed } \\
\hline $\begin{array}{l}\text { Process Impacts } \\
\text { Study }\end{array}$ & 3 & $\begin{array}{l}\text { This study should be expanded to analyze the impacts of } \\
\text { Vadose zone treatment, ancillary equipment removal, and } \\
\text { in-tank equipment removal. The Process Impacts Study to } \\
\text { be completed in FY 1998 will be expanded to include this } \\
\text { scope. }\end{array}$ \\
\hline $\begin{array}{l}\text { Subsurface } \\
\text { Barrier Study }\end{array}$ & 2 & $\begin{array}{l}\text { A study analyzing the alternatives for subsurface barriers } \\
\text { has already been completed (WHC 1995). A decision has } \\
\text { been made not to use subsurface barriers because due to } \\
\text { "poor cost/benefit" (Ecology et al. 1995). This decision } \\
\text { may have to be revisited once source term and transport } \\
\text { model calculations are available. }\end{array}$ \\
\hline $\begin{array}{l}\text { Immobilization } \\
\text { of Residual } \\
\text { Waste Study/ } \\
\text { Demonstrations }\end{array}$ & 4 & $\begin{array}{l}\text { A study analyzing the alternatives for immobilization of the } \\
\text { waste left in the tank after retrieval is necessary to provide } \\
\text { information to the transport studies. Sandia Labs has } \\
\text { proposed to study the alternatives for residual waste } \\
\text { immobilization. }\end{array}$ \\
\hline
\end{tabular}


HNF-SD-HTI-TX-001

Revision 0

\subsection{CONTINUING ALTERNATIVES GENERATION AND ANALYSIS PROCESS}

The AGA process for the HTI is a complex, yet systematic process addressing all actions and decisions. This requires a comprehensive planning process that is tracked, expanded, and updated as necessary in the Draft SST Tank Closure Plan. The overall HTI AGA process is illustrated in Figure 5 and discussed in Section 3.0. As shown in Figures 2 and 6, many related and dependent studies are planned to support the development of closure criteria, the recommendation of these criteria to the Tri-Party Agreement, public, and stakeholders, and the final decision process through the National Environmental Policy Act (NEPA).

This plan has collected and evaluated the plans and information generated in the past, provided an evaluation of need, necessity and sufficiency of new information needed, and a description of the path to final approval of end-state criteria for AX Tank Farm. 
HNF-SD-HTI-TX-001

Revision 0

This page intentionally left blank. 
HNF-SD-HTI-TX-001

Revision 0

\subsection{REFERENCES}

10 CFR 430.1, "Life-Cycle Asset Management", Code of Federal Regulations, as amended.

10 CFR 830.120, "Nuclear Quality Management", Code of Federal Regulations, as amended.

10 CFR 835, "Occupational Radiation Protection", Code of Federal Regulations, as amended.

10 CFR 1021, "NEPA Implementation", Code of Federal Regulations, as amended.

40 CFR 61, "National Emissions Standard for Hazardous Air Pollutants Program," Code of Federal Regulations, as amended.

40 CFR 122-136, "National Pollutant Discharge Elimination System", Code of Federal Regulations, as amended.

40 CFR 191, "Environmental Radiation Protection Standards for Management and Disposal of Spent Nuclear Fuel, High-Level and Transuranic Radioactive Wastes", Code of Federal Regulations, as amended.

40 CFR 1500-1508, "National Environmental Policy Act," Code of Federal Regulations, as amended.

Comprehensive Environmental Response, Compensation, and Liability Act of 1980, Public Law 96-510, 94 Stat. 2767, 42 USC 9601 et seq.

DOE, et al., 1996, Required Percent Waste Retrieval, Memorandum of Understanding, Between U.S. Department of Energy and Washington State Department of Ecology, August 7, 1998, U.S. Department of Energy, Richland Operations Office, Richland, Washington.

DOE Order 5400, 1996, Environmental Protection, U.S. Department of Energy, Washington, D.C.

DOE Order 5400.5, 1996, Radiation Protection of the Public, U.S. Department of Energy, Washington, D.C.

DOE Order 5820.2A, 1996, Waste Management, U.S. Department of Energy, Washington, D.C.

DOE-RL, 1993, Focused Feasibility Study of Engineered Barriers, DOE/RL-1993-33, U.S. Department of Energy, Richland Operations Office, Richland, Washington. 


\section{Revision 0}

DOE-RL, 1996, Single-Shell Tank Closure Work Plan, U.S. Department of Energy, Richland Operations Office, Richland, Washington.

Ecology, DOE, and EPA, 1994, Hanford Federal Facility Agreement and Consent Order Change Form M-45-93-01, Approved January 25, 1994, Process for Determining the Limit of Technology for SST Retrieval, Department of Energy, Richland Operations Office, Richland, Washington, U.S. Environmental Protection Agency, and Washington State Department of Ecology, Olympia, Washington.

Ecology, DOE, and EPA, 1995, Hanford Federal Facility Agreement and Consent Order Change Form M-45-95-01, Approved May 11, 1995, New Interim Milestones M-45-08, M-45-09 and Completion of M-45-07B, Department of Energy, Richland Operations Office, Richland, Washington, U.S. Environmental Protection Agency, and Washington State Department of Ecology, Olympia, Washington.

Ecology, DOE, and EPA, 1996, Hanford Federal Facility Agreement and Consent Order, Fifth Amendment, U.S. Department of Energy, Richland Operations Office, Richland, Washington, U.S. Environmental Protection Agency, and Washington State Department of Ecology, Olympia, Washington.

FDH, 1997, Path Forward for Developing Retrieval Performance Evaluation Criteria, working paper, Fluor Daniel Hanford Company, Richland, Washington.

JEG, 1997a, Revised Stakeholder Involvement Plan, CC:Mail Message, Robert W. Lober to Carolyn C. Haass, et al., June 11, 1997, Jacobs Engineering Group, Inc., Richland, Washington.

JEG, 1997b, Stakeholder Participation Plan for the Retrieval Performance Evaluation Criteria Assessment, Jacobs Engineering Group, Inc., Richland, Washington.

JEG, 1997c, Identification of Tank Waste Retrieval Regulatory Performance Measures, Jacobs Engineering Group, Inc., Richland, Washington.

JEG, 1997d, Retrieval Performance Evaluation Criteria Assessment Work Plan, Jacobs Engineering Group, Inc., Richland, Washington.

National Environmental Policy Act of 1969, Public Law, 42 USC 4321 et seq.

NRC, 1997, Regulatory Requirements, U.S. Nuclear Regulatory Commission, Washington, D.C.

Resource Conservation and Recovery Act of 1976, Public Law 94-580, 90 Stat. 2795, 42 USC 6901 et seq. 


\section{Revision 0}

WAC 173-303, 1997, "Dangerous Waste Regulations," Washington Administrative Code, as amended.

WAC 173-401, 1994, "Washington State Air Operating Permit Regulations," Washington Administrative Code, as amended.

WAC 246-247, "Radiation Air Emissions Program," Washington Administrative Code, as amended.

WHC, 1995, Feasibility Study of Tank Leakage Mitigation Using Subsurface Barriers, WHC-SD-WM-ES-300, Rev. 1, Westinghouse Hanford Company, Richland, Washington.

WHC, 1996a, Hanford Tanks Initiative Plan, WHC-SD-WM-PMP-022, Rev. 0, Westinghouse Hanford Company, Richland, Washington.

WHC, 1996b, Mission Analysis Report for the Hanford Tanks Initiative, WHC-SD-WM-MAR-012, Rev. 0, Westinghouse Hanford Company, Richland, Washington.

WHC, 1996c, TWRS Systems Engineering Manual, WHC-IP-1231, Section 3.0, "Alternatives Generation and Analysis," Westinghouse Hanford Company, Richland, Washington. 
HNF-SD-HTI-TX-001

Revision 0

This page intentionally left blank. 
HNF-SD-HTI-TX-001

Revision 0

APPENDIX A

COMPARISON OF INFORMATION NEEDS 
HNF-SD-HTI-TX-001

Revision 0

This page intentionally left blank. 


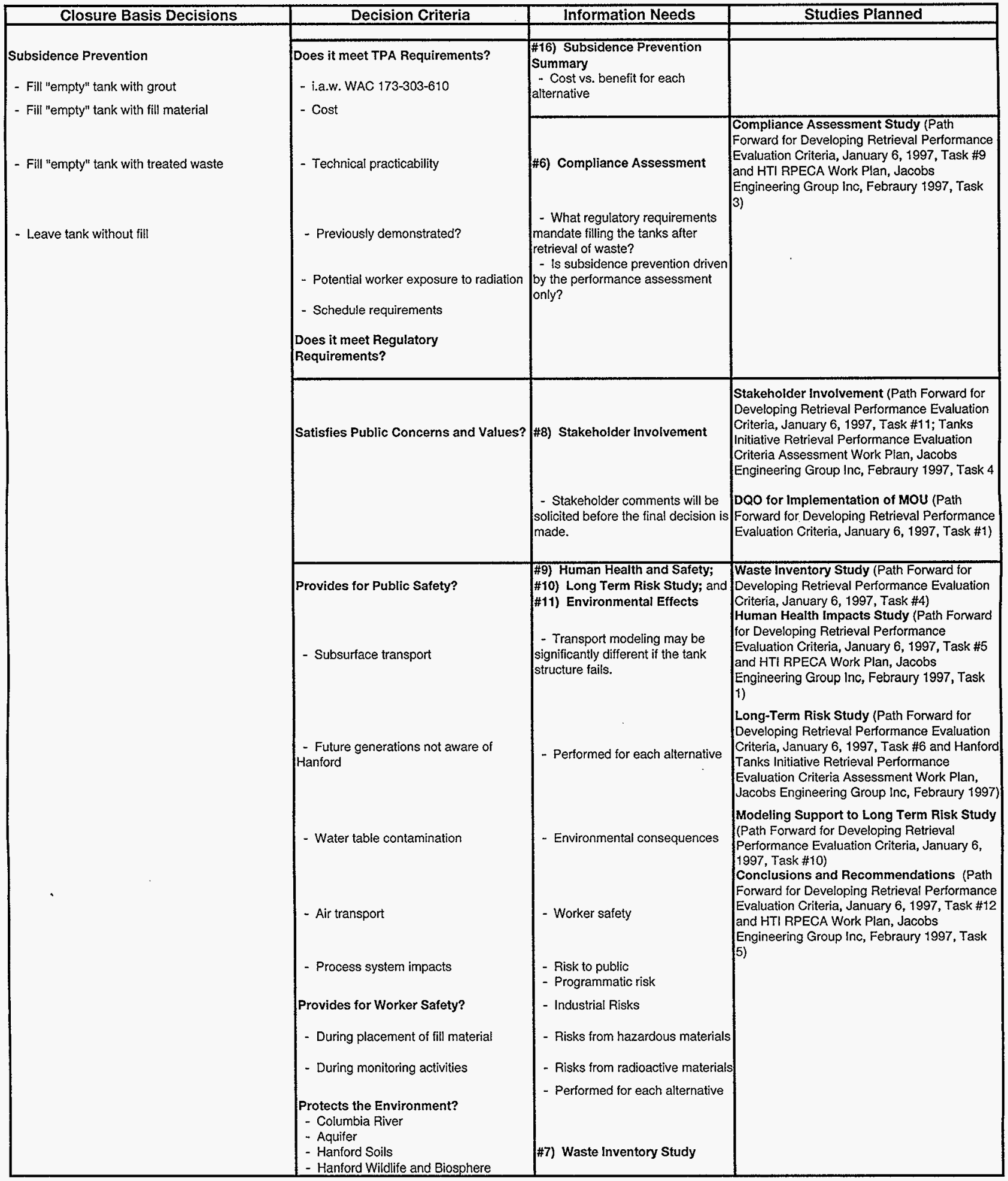




\begin{tabular}{|c|c|c|c|}
\hline Closure Basis Decision & Decision Criteria & Information Needs & Studies Planned \\
\hline $\begin{array}{l}\text { Amount and Classification of Residual Waste } \\
\text { Allowed to Remain } \\
\text { - Decontaminate to bare metal } \\
\text { - Retrieve to w/1 TPA minimum requirement } \\
\text { (Retrieve to } 99 \% \text { ) } \\
\text { - Best any technology can perform } \\
\text { - Do not retrieve anything } \\
\text { - Curies and radionuclides in residual }\end{array}$ & $\begin{array}{l}\text { Does it meet TPA Requirements? } \\
\text { - As much as technically possible } \\
\text { - }<360 \text { cu. ft. in each } 100 \text { series tank } \\
\text { - }<30 \text { cu. ft. in each } 200 \text { series tank } \\
\text { - i.a.w. WAC } 173-303-610 \\
\text { - Cost } \\
\text { - Technical practicability } \\
\text { - Previously demonstrated? } \\
\text { - Potential worker exposure to radiation } \\
\text { EPA / WDOE regulates } \\
\text { - HLW therefore NRC regulates } \\
\text { - Schedule requirements } \\
\text { Does Residual Meet NRC } \\
\text { Requirements? }\end{array}$ & $\begin{array}{l}\text { \#1) Retrieval Demonstrations } \\
\text { - Cost vs. waste retrieved } \\
\text { - Maximum achievable } \\
\text { - Worker exposure for each } \\
\text { alternative } \\
\text { - Production rates } \\
\text { - This study must span the } \\
\text { spectrum of available, plausible } \\
\text { technologies to gain stakeholder } \\
\text { and regulator support for the final } \\
\text { recommendation. } \\
\text { \#6) Compliance Assessment } \\
\text { - Assess the impacts on } \\
\text { regulatory compliance with each } \\
\text { regulatory agency of various levels } \\
\text { of retrieval } \\
\text { - Determine at what level NRC } \\
\text { allows remaining waste to be } \\
\text { considered incidental. }\end{array}$ & $\begin{array}{l}\text { Compliance Assessment Study (Path } \\
\text { Forward for Developing Retrieval Performance } \\
\text { Evaluation Criteria, January } 6,1997 \text {, Task } \$ 9 \\
\text { and HTI RPECA Work Plan, Jacobs } \\
\text { Engineering Group Inc, Febraury 1997, Task } \\
\text { 3) } \\
\qquad\end{array}$ \\
\hline & Satisfies Public Concerns and Values? & $\begin{array}{l}\text { \#8) Stakeholder Involvement } \\
\text { - After technical information is } \\
\text { developed, the public should be } \\
\text { involved in the final decision of } \\
\text { how much waste should be } \\
\text { retrieved. }\end{array}$ & $\begin{array}{l}\text { Stakeholder Involvement (Path Forward for } \\
\text { Developing Retrieval Performance Evaluation } \\
\text { Criteria, January 6, 1997, Task \#11; Tanks } \\
\text { Initiative Retrieval Performance Evaluation } \\
\text { Criteria Assessment Work Plan, Jacobs } \\
\text { Engineering Group Inc, Febraury 1997, Task } 4 \\
\\
\text { DQO for Implementation of MOU (Path } \\
\text { Forward for Developing Retrieval Performance } \\
\text { Evaluation Criteria, January 6, 1997, Task \#1) }\end{array}$ \\
\hline$\frac{\substack{b \\
\dot{u}}}{p_{0}}$ & $\begin{array}{l}\text { Provides for Public Safety? } \\
\text { - Subsurface transport } \\
\text { - Future generations not aware of } \\
\text { Hanford } \\
\text { - Water table contamination } \\
\text { Protects the Environment? } \\
\text { - Columbia River } \\
\text { - Aquifer } \\
\text { - Hanford Soils } \\
\text { - Hanford Wildlife and Biosphere } \\
\text { Provides for Worker Safety? } \\
\text { - During retrieval and treatment } \\
\text { - During monitoring activities } \\
\text { - Radiation exposure considered } \\
\text { - Process system impacts }\end{array}$ & $\begin{array}{l}\text { \#9) Human Health and Safety; } \\
\text { \#10) Long Term Risk Study; and } \\
\# 11 \text { ) Environmental Effects } \\
\text { - Transport modeling } \\
\text { - Requires waste } \\
\text { characterization and inventory } \\
\\
\text { - Environmental consequences } \\
\text { - This study will determine how } \\
\text { remaining waste will effect the } \\
\text { public and the environment. } \\
\text { - All transport paths will be } \\
\text { studied for various levels of } \\
\text { remaining waste. } \\
\text { - Worker safety from all stages of } \\
\text { waste management. } \\
\text { - Risk to public during and after } \\
\text { retrieval } \\
\text { - Industrial Risks } \\
\text { - Risks from hazardous materials } \\
\text { - Risks from radioactive } \\
\text { materials } \\
\text { - Performed for varying levels of } \\
\text { waste allowed to remain } \\
\# 3 \text { ) Process System Impacts } \\
\text { \#7) Waste Inventory Study }\end{array}$ & $\begin{array}{l}\text { Waste Inventory Study (Path Forward for } \\
\text { Developing Retrieval Performance Evaluation } \\
\text { Criteria, January 6, 1997, Task \#4) } \\
\text { Process Impacts Study (Path Forward for } \\
\text { Developing Retrieval Performance Evaluation } \\
\text { Criteria, January 6, 1997, Task \#7) } \\
\text { Human Health Impacts Study (Path Forward } \\
\text { for Developing Retrieval Performance } \\
\text { Evaluation Criteria, January 6, 1997, Task \#5 } \\
\text { and HTI RPECA Work Plan, Jacobs } \\
\text { Engineering Group Inc, Febraury 1997, Task } \\
\text { 1) } \\
\text { Long-Term Risk Study (Path Forward for } \\
\text { Developing Retrieval Performance Evaluation } \\
\text { Criteria, January 6, 1997, Task \#6 and Hanford } \\
\text { Tanks Initiative Retrieval Performance } \\
\text { Evaluation Criteria Assessment Work Plan, } \\
\text { Jacobs Engineering Group Inc, Febraury 1997) } \\
\text { Modeling Support to Long Term Risk Study } \\
\text { (Path Forward for Developing Retrieval } \\
\text { Performance Evaluation Criteria, January 6, } \\
\text { 1997, Task \#10) } \\
\text { Conclusions and Recommendations (Path } \\
\text { Forward for Developing Retrieval Performance } \\
\text { Evaluation Criteria, January 6, 1997, Task \#12 } \\
\text { and HTI RPECA Work Plan, Jacobs } \\
\text { Engineering Group Inc, Febraury 1997, Task } \\
\text { 5) }\end{array}$ \\
\hline
\end{tabular}




\begin{tabular}{|c|c|c|c|}
\hline Closure Basis Decision & Decision Criteria & Information Needs & Studies Planned \\
\hline \multirow[t]{3}{*}{$\begin{array}{l}\text { Amount of Waste Leakage Allowable During } \\
\text { Retrieval }\end{array}$} & $\begin{array}{l}\text { Does it meet Regulatory } \\
\text { Requirements? }\end{array}$ & $\begin{array}{l}\text { \#1) Retrieval Demonstrations } \\
\text { - Cost vs. waste retrieved } \\
\text { - Maximum achievable } \\
\text { - Worker exposure for each } \\
\text { alternative } \\
\text { - Production rates } \\
\text { - This study must span the } \\
\text { spectrum of available, plausible } \\
\text { technologies to gain stakeholder } \\
\text { and regulator support for the final } \\
\text { recommendation. } \\
\text { \#6) Compliance Assessment } \\
\text { - Assess the impacts on } \\
\text { regulatory compliance with each } \\
\text { regulatory agency of various levels } \\
\text { of waste leakage during retrieval }\end{array}$ & $\begin{array}{l}\text { Retrieval Demonstrations } \\
\\
\text { Compliance Assessment Study (Path } \\
\text { Forward for Developing Retrieval Performance } \\
\text { Evaluation Criteria, January } 6,1997, \text { Task \#9 } \\
\text { and HTI RPECA Work Plan, Jacobs } \\
\text { Engineering Group Inc, Febraury 1997, Task } \\
\text { 3) } \\
\end{array}$ \\
\hline & Satisfies Public Concerns and Values? & $\begin{array}{l}\text { \#8) Stakeholder Involvement } \\
\text { - After technical information is } \\
\text { developed, the public should be } \\
\text { involved in the final decision of } \\
\text { how much waste should be } \\
\text { allowed to leak during retrieval. }\end{array}$ & $\begin{array}{l}\text { Stakeholder Involvement (Path Fonward for } \\
\text { Developing Retrieval Performance Evaluation } \\
\text { Criteria, January 6, 1997, Task \#11; Tanks } \\
\text { Initiative Retrieval Performance Evaluation } \\
\text { Criteria Assessment Work Plan, Jacobs } \\
\text { Engineering Group Inc, Febraury 1997, Task } 4 \\
\\
\text { DQO for Implementation of MOU (Path } \\
\text { Forward for Developing Retrieval Performance } \\
\text { Evaluation Criteria, January 6,1997, Task \#1) }\end{array}$ \\
\hline & $\begin{array}{l}\text { Provides for Public Safety? } \\
\text { - Subsurface transport } \\
\text { - Future generations not aware of } \\
\text { Hanford } \\
\text { - Water table contamination } \\
\text { Protects the Environment? } \\
\text { - Columbia River } \\
\text { - Aquifer } \\
\text { - Hanford Soils } \\
\text { - Hanford Wildlife and Biosphere } \\
\text { - During retrieval and treatment } \\
\text { - During monitoring activities } \\
\text { - Radiation exposure considered } \\
\end{array}$ & $\begin{array}{l}\text { \#9) Human Health and Safety; } \\
\text { \#10) Long Term Risk Study; and } \\
\text { \#11) Environmental Effects } \\
\text { - Transport modeling } \\
\text { - Requires waste } \\
\text { characterization and inventory } \\
\text { - This study will determine how } \\
\text { the leaking waste will effect the } \\
\text { public and the environment. } \\
\text { - All transport paths will be } \\
\text { studied for various levels of waste } \\
\text { allowed to leak. } \\
\text { \#7) Waste Inventory Study } \\
\text { - Worker safety from all stages of } \\
\text { waste management. } \\
\text { - Risk to public during and after } \\
\text { retrieval } \\
\text { - Industrial Risks } \\
\text { - Risks from hazardous materials } \\
\text { - Risks from radioactive materials } \\
\text { - Performed for varying levels of } \\
\text { a }\end{array}$ & $\begin{array}{l}\text { Waste Inventory Study (Path Forward for } \\
\text { Developing Retrieval Performance Evaluation } \\
\text { Criteria, January 6, 1997, Task \#4) } \\
\text { Process Impacts Study (Path Forward for } \\
\text { Developing Retrieval Performance Evaluation } \\
\text { Criteria, January 6, 1997, Task \#7) } \\
\text { Human Health Impacts Study (Path Forward } \\
\text { for Developing Retrieval Performance } \\
\text { Evaluation Criteria, January 6, 1997, Task \#5 } \\
\text { and HTI RPECA Work Plan, Jacobs } \\
\text { Engineering Group Inc, Febraury 1997, Task } \\
\text { 1) } \\
\text { Long-Term Risk Study (Path Forward for } \\
\text { Developing Retrieval Performance Evaluation } \\
\text { Criteria, January 6, 1997, Task \#6 and Hanford } \\
\text { Tanks Initiative Retrieval Performance } \\
\text { Evaluation Criteria Assessment Work Plan, } \\
\text { Jacobs Engineering Group Inc, Febraury 1997) } \\
\text { Modeling Support to Long Term Risk Study } \\
\text { (Path Forward for Developing Retrieval } \\
\text { Performance Evaluation Criteria, January 6, } \\
\text { 1997, Task \#10) } \\
\text { Conclusions and Recommendations (Path } \\
\text { Forward for Developing Retrieval Performance } \\
\text { Evaluation Criteria, January 6, 1997, Task \#12 } \\
\text { and HTI RPECA Work Plan, Jacobs } \\
\text { Engineering Group Inc, Febraury 1997, Task } \\
\text { 5) } \\
\end{array}$ \\
\hline
\end{tabular}




\begin{tabular}{|c|c|c|c|}
\hline Closure Basis Decision & Decision Criteria & Information Needs & Studies Planned \\
\hline \multirow[t]{4}{*}{ Treatment of Residual Waste } & $\begin{array}{l}\text { Does it meet Regulatory } \\
\text { Requirements? }\end{array}$ & $\begin{array}{l}\text { \#6) Compliance Assessment } \\
\text { - For an assumed amount of } \\
\text { waste left in the SSTs after } \\
\text { retrieval, what regulatory } \\
\text { requirements apply. }\end{array}$ & $\begin{array}{l}\text { Compliance Assessment Study (Path } \\
\text { Fonward for Developing Retrieval Performance } \\
\text { Evaluation Criteria, January 6, 1997, Task \#9 } \\
\text { and HTI RPECA Work Plan, Jacobs } \\
\text { Engineering Group Inc, Febraury 1997, Task } \\
\text { 3) }\end{array}$ \\
\hline & Satisfies Public Concerns and Values? & $\begin{array}{l}\text { \#8) Stakeholder Involvement } \\
\text { - Once the alternatives are } \\
\text { understood, the stakeholders will } \\
\text { be involved in the decision making } \\
\text { process. }\end{array}$ & $\begin{array}{l}\text { Stakeholder Involvement (Path Forward for } \\
\text { Developing Retrieval Performance Evaluation } \\
\text { Criteria, January 6, 1997, Task \#11; Tanks } \\
\text { initiative Retrieval Performance Evaluation } \\
\text { Criteria Assessment Work Plan, Jacobs } \\
\text { Engineering Group Inc, Febraury 1997, Task } 4 \\
\text { DQO for Implementation of MOU (Path } \\
\text { Forward for Developing. Retrieval Performance } \\
\text { Evaluation Criteria, January 6, 1997, Task \#1) }\end{array}$ \\
\hline & $\begin{array}{l}\text { Provides for Public Safety? } \\
\text { - Subsurface transport } \\
\text { - Future generations not aware of } \\
\text { Hanford }\end{array}$ & $\begin{array}{l}\text { \#9) Human Health and Safety; } \\
\text { \#10) Long Term Risk Study; and } \\
\text { \#11) Environmental Effects } \\
\text { - Worker safety } \\
\text { - Risk to public }\end{array}$ & $\begin{array}{l}\text { Waste Inventory Study (Path Forward for } \\
\text { Developing Retrieval Performance Evaluation } \\
\text { Criteria, January 6, 1997, Task \#4) } \\
\text { Human Health Impacts Study (Path Forward } \\
\text { for Developing Retrieval Performance } \\
\text { Evaluation Criteria, January 6, 1997, Task \#5 } \\
\text { and HTI RPECA Work Plan, Jacobs } \\
\text { Engineering Group Inc, Febraury 1997, Task } \\
\text { 1) } \\
\text { Long-Term Risk Study (Path Fonward for } \\
\text { Developing Retrieval Performance Evaluation } \\
\text { Criteria, January 6, 1997, Task \#6 and Hanford } \\
\text { Tanks Initiative Retrieval Performance } \\
\text { Evaluation Criteria Assessment Work Plan, } \\
\text { Jacobs Engineering Group Inc, Febraury 1997) }\end{array}$ \\
\hline & $\begin{array}{l}\text { - Water table contamination } \\
\text { - Air transport } \\
\text { Provides for Worker Safety? } \\
\text { - During retrieval and treatment } \\
\text { - During monitoring activities } \\
\text { - Radiation exposure considered } \\
\\
\text { Protects the Environment? } \\
\text { - Columbia River } \\
\text { - Aquifer } \\
\text { - Hanford Soils } \\
\text { - Hanford Wildlife and Biosphere }\end{array}$ & $\begin{array}{l}\text { - Programmatic risk } \\
\text { - Industrial Risks } \\
\text { - Risks from hazardous materials } \\
\text { - Risks from radioactive materials } \\
\text { - Performed for each set of } \\
\text { alternatives } \\
\text { - Transport modeling } \\
\text { - Process system impacts } \\
\text { - Performed for each set of } \\
\text { alternatives } \\
\text { - Requires waste } \\
\text { characterization and inventory } \\
\text { - Environmental consequences } \\
\text { \#7) Waste Inventory Study } \\
\text { \#15) Immobilization } \\
\text { Demonstrations } \\
\text { - Each alternative for treatment } \\
\text { of residual waste must be } \\
\text { reviewed. Some may require } \\
\text { demonstration. }\end{array}$ & $\begin{array}{l}\text { Modeling Support to Long Term Risk Study } \\
\text { (Path Fonward for Developing Retrieval } \\
\text { Performance Evaluation Criteria, January 6, } \\
\text { 1997, Task \#10) } \\
\text { Conclusions and Recommendations (Path } \\
\text { Forward for Developing Retrieval Performance } \\
\text { Evaluation Criteria, January 6, 1997, Task \#12 } \\
\text { and HTi RPECA Work Plan, Jacobs } \\
\text { Engineering Group Inc, Febraury 1997, Task } \\
\text { 5) } \\
\text { Is } \\
\text { s. }\end{array}$ \\
\hline
\end{tabular}




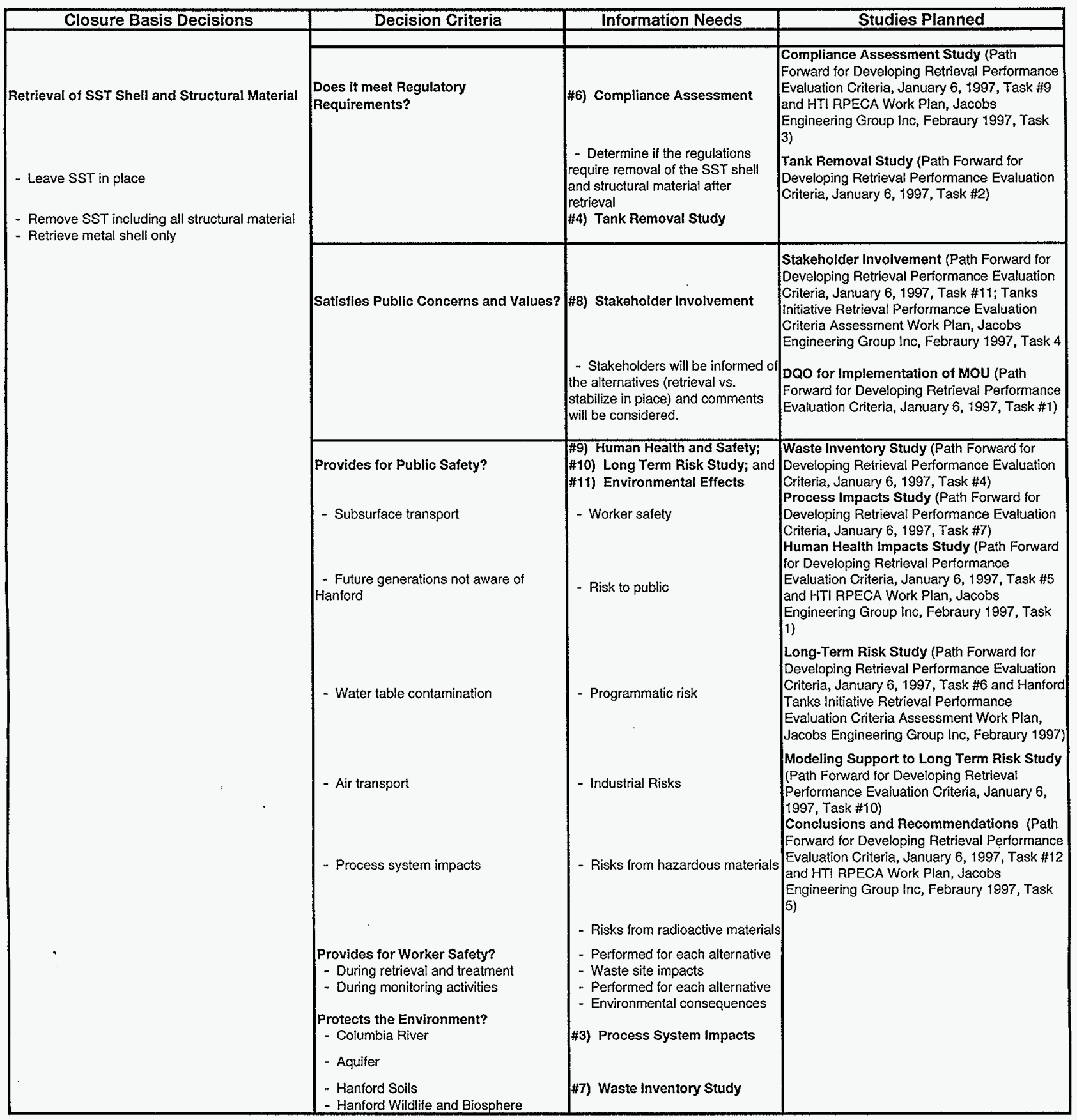




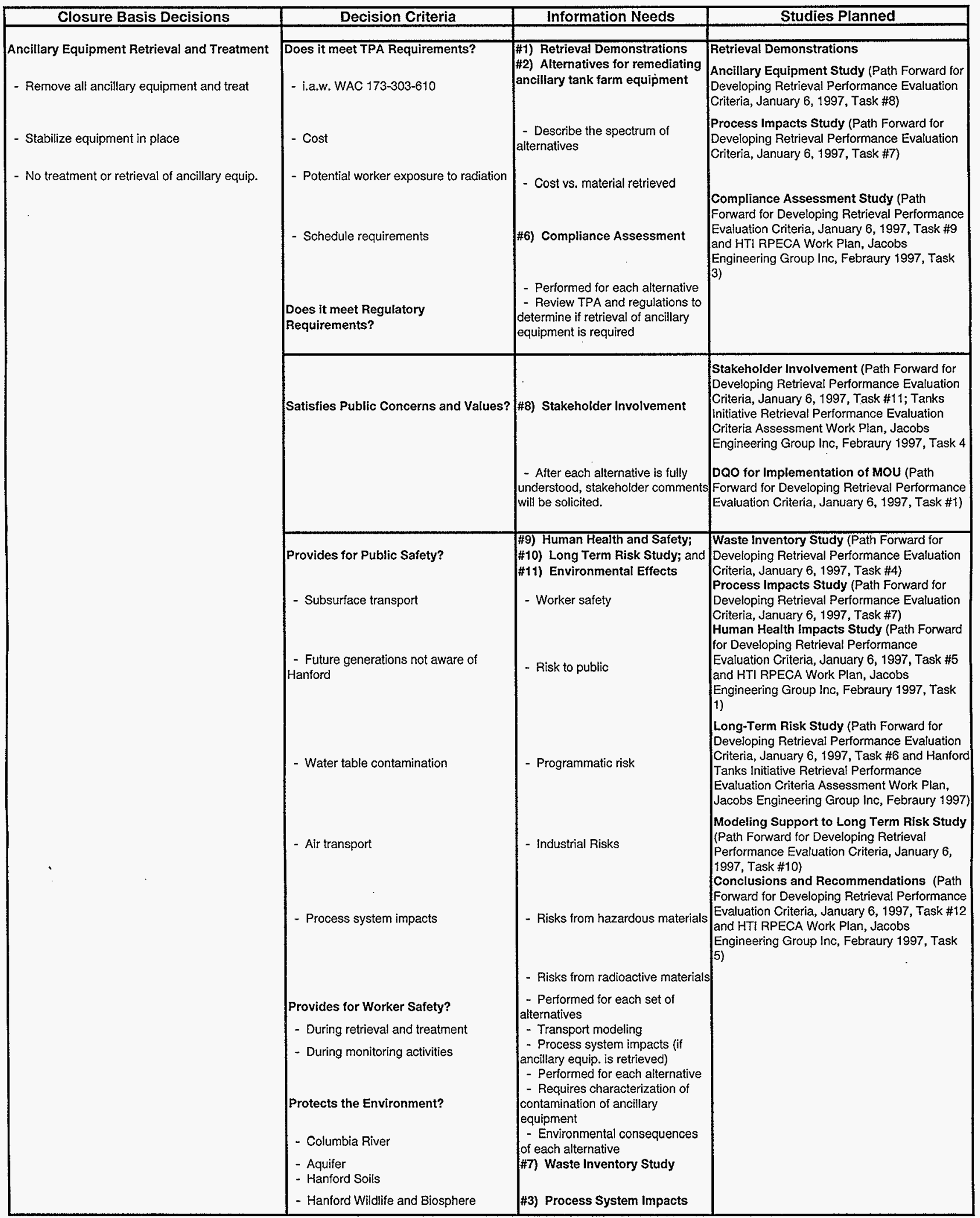




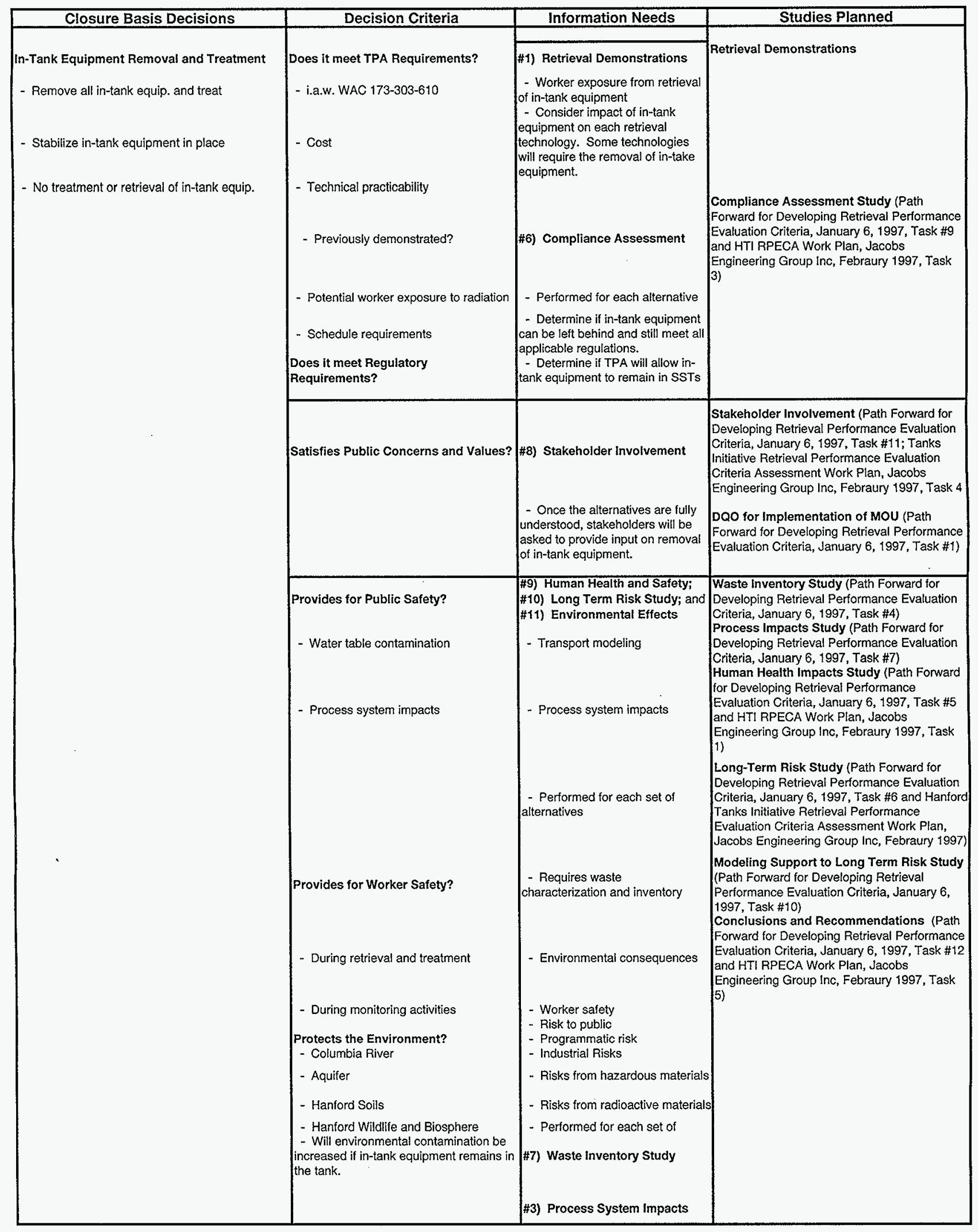




\begin{tabular}{|c|c|c|c|}
\hline Closure Basis Decisions & Decision Criteria & Information Needs & Studies Planned \\
\hline $\begin{array}{l}\text { - Treat the soil in place } \\
\text { - Retrieve and treat the soil } \\
\text { - Don't treat the soil }\end{array}$ & $\begin{array}{l}\text { Does it meet TPA Requirements? } \\
\text { - i.a.w. WAC } 173-303-610 \\
\text { - Cost } \\
\text { - Potential worker exposure to radiation } \\
\text { - Schedule requirements } \\
\text { Does it meet Regulatory } \\
\text { Requirements? }\end{array}$ & $\begin{array}{l}\text { \#6) Compliance Assessment } \\
\text { - Performed for each alternative } \\
\text { - Will each alternative satisfy } \\
\text { TPA and other regulatory } \\
\text { requirements } \\
\text { \#5) Soil Remediation Study }\end{array}$ & $\begin{array}{l}\text { Soil Remediation Study (Path Forward for } \\
\text { Developing Retrieval Performance Evaluation } \\
\text { Criteria, January 6, 1997, Task \#3) } \\
\text { Compliance Assessment Study (Path } \\
\text { Fonward for Developing Retrieval Performance } \\
\text { Evaluation Criteria, January 6, 1997, Task \#9 } \\
\text { and HTI RPECA Work Plan, Jacobs } \\
\text { Engineering Group lnc, Febraury 1997, Task } \\
\text { 3) }\end{array}$ \\
\hline • & $\begin{array}{l}\text { Provides for Public Safety? } \\
\text { - Subsurface transport } \\
\text { - Future generations not aware of } \\
\text { Hanford } \\
\text { - Water table contamination } \\
\text { Protects the Environment? } \\
\text { - Air transport } \\
\text { - Aquifer } \\
\text { - Hanford Soils } \\
\text { - Hanford Wildlife and Biosphere } \\
\text { - Process system impacts } \\
\text { Provides for Worker Safety? } \\
\text { - During retrieval and treatment } \\
\text { - During monitoring activities } \\
\end{array}$ & \begin{tabular}{|l} 
\#9) Human Health and Safety; \\
\#10) Long Term Risk Study; and \\
\#11) Environmental Effects \\
- Transport modeling \\
- Process system impacts \\
- Performed for each alternative \\
- Requires soil characterization \\
and inventory \\
\#7) Waste Inventory Study \\
\#3) Process System Impacts \\
- Environmental consequences \\
- Worker safety \\
- Risk to public \\
- Programmatic risk \\
- Industrial Risks \\
- Risks from hazardous materials \\
- Risks from radioactive materials \\
- Performed for each alternative
\end{tabular} & $\begin{array}{l}\text { Waste Inventory Study (Path Forward for } \\
\text { Developing Retrieval Performance Evaluation } \\
\text { Criteria, January 6, 1997, Task \#4) } \\
\text { Process Impacts Study (Path Forward for } \\
\text { Developing Retrieval Performance Evaluation } \\
\text { Criteria, January 6, 1997, Task \#7) } \\
\text { Human Health Impacts Study (Path Forward } \\
\text { for Developing Retrieval Performance } \\
\text { Evaluation Criteria, January 6, 1997, Task \#5 } \\
\text { and HTI RPECA Work Plan, Jacobs } \\
\text { Engineering Group Inc, Febraury 1997, Task } \\
\text { 1) } \\
\text { Long-Term Risk Study (Path Forward for } \\
\text { Developing Retrieval Performance Evaluation } \\
\text { Criteria, January 6, 1997, Task \#6 and Hanford } \\
\text { Tanks Initiative Retrieval Performance } \\
\text { Evaluation Criteria Assessment Work Plan, } \\
\text { Jacobs Engineering Group Inc, Febraury 1997) } \\
\text { Modeling Support to Long Term Risk Study } \\
\text { (Path Forward for Developing Retrieval } \\
\text { Performance Evaluation Criteria, January 6, } \\
\text { 1997, Task \#10) } \\
\text { Conclusions and Recommendations (Path } \\
\text { Forward for Developing Retrieval Performance } \\
\text { Evaluation Criteria, January 6, 1997, Task \#12 } \\
\text { and HTI RPECA Work Plan, Jacobs } \\
\text { Engineering Group Inc, Febraury 1997, Task } \\
\text { 5) }\end{array}$ \\
\hline
\end{tabular}




\begin{tabular}{|c|c|c|c|}
\hline Closure Basis Decisions & Decision Criteria & Information Needs & Studies Planned \\
\hline $\begin{array}{l}\text { - Treatment } \\
\text { - Vapor extraction } \\
\text { - Other treatment }\end{array}$ & $\begin{array}{l}\text { Does it meet TPA Requirements? } \\
\text { - i.a.w. WAC } 173-303-610 \\
\text { - Cost } \\
\text { - Potential worker exposure to radiation } \\
\text { - Schedule requirements } \\
\text { Does it meet Regulatory } \\
\text { Requirements? }\end{array}$ & $\begin{array}{l}\text { \#12) Vadose Zone Treatment } \\
\text { Alternatives } \\
\text { - Vadose zone treatment } \\
\text { techniques should be listed by } \\
\text { cost, efficiency, and waste } \\
\text { products produced. } \\
\text { \#5) Soil Remediation Study } \\
\text { \#6) Compliance Assessment } \\
\text { - Performed for each alternative } \\
\text { - Is vadose zone treatment a } \\
\text { requirement of TPA or any } \\
\text { regulation? }\end{array}$ & $\begin{array}{l}\text { Compliance Assessment Study (Path } \\
\text { Forward for Developing Retrieval Performance } \\
\text { Evaluation Criteria, January 6, 1997, Task \#9 } \\
\text { and HTI RPECA Work Plan, Jacobs } \\
\text { Engineering Group Inc, Febraury 1997, Task } \\
\text { 3) }\end{array}$ \\
\hline & Satisfies Public Concerns and Values? & $\begin{array}{l}\text { \#8) Stakeholder Involvement } \\
\text { - Once the alternatives are } \\
\text { technically understood, } \\
\text { stakeholders will be informed of } \\
\text { the alternatives and asked to } \\
\text { comment. }\end{array}$ & $\begin{array}{l}\text { Stakeholder Involvement (Path Forward for } \\
\text { Developing Retrieval Performance Evaluation } \\
\text { Criteria, January 6, 1997, Task \#11; Tanks } \\
\text { Initiative Retrieval Performance Evaluation } \\
\text { Criteria Assessment Work Plan, Jacobs } \\
\text { Engineering Group Inc, Febraury 1997, Task } 4 \\
\\
\text { DQO for Implementation of MOU (Path } \\
\text { Forward for Developing Retrieval Performance } \\
\text { Evaluation Criteria, January 6, 1997, Task \#1) }\end{array}$ \\
\hline • & $\begin{array}{l}\text { Provides for Public Safety? } \\
\text { - Subsurface transport } \\
\text { - Future generations not aware of } \\
\text { Hanford } \\
\text { - Water table contamination } \\
\text { Protects the Environment? } \\
\text { - Columbia River } \\
\text { - Air transport } \\
\text { - Aquifer } \\
\text { - Hanford Soils } \\
\text { - During monitoring activities } \\
\text { selected }\end{array}$ & 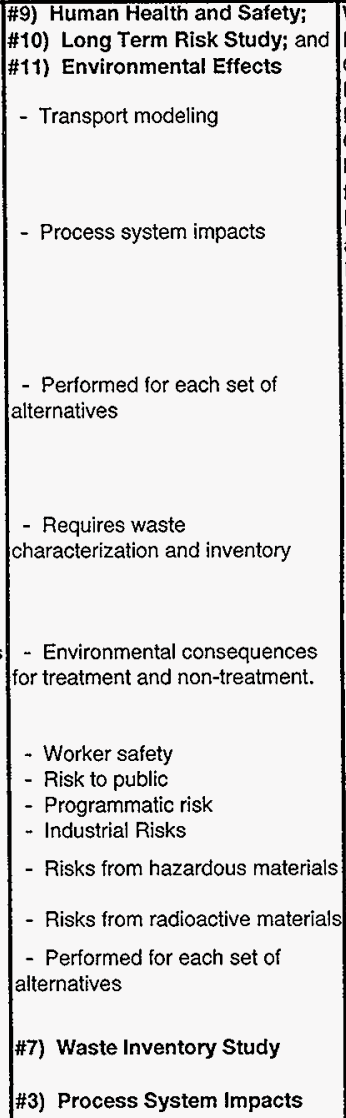 & $\begin{array}{l}\text { Waste Inventory Study (Path Forward for } \\
\text { Developing Retrieval Performance Evaluation } \\
\text { Criteria, January 6, 1997, Task \#4) } \\
\text { Process Impacts Study (Path Forward for } \\
\text { Developing Retrieval Performance Evaluation } \\
\text { Criteria, January 6, 1997, Task \#7) } \\
\text { Human Health Impacts Study (Path Forward } \\
\text { for Developing Retrieval Performance } \\
\text { Evaluation Criteria, January 6, 1997, Task \#5 } \\
\text { and HTI RPECA Work Plan, Jacobs } \\
\text { Engineering Group Inc, Febraury 1997, Task } \\
\text { 1) } \\
\text { Long-Term Risk Study (Path Forward for } \\
\text { Developing Retrieval Performance Evaluation } \\
\text { Criteria, January 6, 1997, Task \#6 and Hanford } \\
\text { Tanks Initiative Retrieval Performance } \\
\text { Evaluation Criteria Assessment Work Plan, } \\
\text { Jacobs Engineering Group Inc, Febraury 1997) } \\
\text { Modeling Support to Long Term Risk Study } \\
\text { (Path Forward for Developing Retrieval } \\
\text { Performance Evaluation Criteria, January 6, } \\
\text { 1997, Task \#10) } \\
\text { Conclusions and Recommendations (Path } \\
\text { Forward for Developing Retrieval Performance } \\
\text { Evaluation Criteria, January 6, 1997, Task \#12 } \\
\text { and HTI RPECA Work Plan, Jacobs } \\
\text { Engineering Group inc, Febraury 1997, Task } \\
\text { 5) }\end{array}$ \\
\hline
\end{tabular}




\begin{tabular}{|c|c|c|c|}
\hline Closure Basis Decisions & Decision Criteria & Information Needs & Studies Planned \\
\hline $\begin{array}{l}\text { Treatment Process System Effects } \\
\text { - Treatment of Waste } \\
\text { - Treatment of Ancillary Equipment } \\
\text { - Treatment of Shell and Structural Material } \\
\text { - Treatment of Residual Waste } \\
\text { - Treatment of in-tank Equipment (either in-tank } \\
\text { or after removal) } \\
\text { - Treatment of contamination in soils and } \\
\text { vadose zone }\end{array}$ & $\begin{array}{l}\text { Does it meet TPA Requirements? } \\
\text { - i.a.w. WAC } 173-303-610 \\
\text { - Cost } \\
\text { - Technical practicability } \\
\text { - Previously demonstrated? } \\
\text { - Potential worker exposure during } \\
\text { treatment and disposal } \\
\text { - Schedule requirements } \\
\text { Does it meet Regulatory } \\
\text { Requirements? }\end{array}$ & $\begin{array}{l}\text { \#6) Compliance Assessment } \\
\text { - Performed for each set of } \\
\text { alternatives } \\
\text { - Does each treatment alternative } \\
\text { meet regulatory requirements? } \\
\text { - Itemize which wastes can be } \\
\text { disposed of without treatment }\end{array}$ & $\begin{array}{l}\text { Compliance Assessment Study (Path } \\
\text { Fonward for Developing Retrieval Performance } \\
\text { Evaluation Criteria, January } 6,1997 \text {, Task \#9 } \\
\text { and HTI RPECA Work Plan, Jacobs } \\
\text { Engineering Group Inc, Febraury 1997, Task } \\
\text { 3) }\end{array}$ \\
\hline $\begin{array}{l}\text { Note: This decision is necessary to assure the } \\
\text { global effects are considered when making } \\
\text { treatment and retrieval decisions. }\end{array}$ & Satisfies Public Concerns and Values? & $\begin{array}{l}\text { \#8) Stakeholder Involvement } \\
\text { - As stakeholders comment on } \\
\text { key decisions, they will need to } \\
\text { know the total effects of each } \\
\text { retrieval and treatment decision. }\end{array}$ & $\begin{array}{l}\text { Stakeholder Involvement (Path Forward for } \\
\text { Developing Retrieval Performance Evaluation } \\
\text { Criteria, January 6, 1997, Task \#11; Tanks } \\
\text { Initiative Retrieval Performance Evaluation } \\
\text { Criteria Assessment Work Plan, Jacobs } \\
\text { Engineering Group Inc, Febraury 1997, Task } 4 \\
\\
\text { DQO for Implementation of MOU (Path } \\
\text { Forward for Developing Retrieval Performance } \\
\text { Evaluation Criteria, January 6, 1997, Task \#1) }\end{array}$ \\
\hline - & $\begin{array}{l}\text { Provides for Public Safety? } \\
\text { - Water table contamination } \\
\text { - Air transport } \\
\text { - Each retrieval and treatment } \\
\text { alternative will have different process } \\
\text { system impacts on the public. } \\
\text { Provides for Worker Safety? } \\
\text { Protects the Environment? } \\
\text { - Each retrieval and treatment } \\
\text { system effects on the environment which } \\
\text { must be understood. }\end{array}$ & $\begin{array}{l}\text { \#9) Human Health and Safety; } \\
\text { \#10) Long Term Risk Study; and } \\
\text { \#11) Environmental Effects } \\
\text { - Transport modeling } \\
\text { - Process system impacts } \\
\text { - Performed for each set of } \\
\text { alternatives } \\
\text { - Requires waste } \\
\text { characterization and inventory } \\
\text { \#7) Waste Inventory Study } \\
\text { - Risks from hazardous and } \\
\text { - Environmental consequences } \\
\text { - Wortive materials } \\
\text { - Risk to public } \\
\text { - Programmatic risk } \\
\text { - Industrial Risks }\end{array}$ & $\begin{array}{l}\text { Waste Inventory Study (Path Forward for } \\
\text { Developing Retrieval Performance Evaluation } \\
\text { Criteria, January 6, 1997, Task \#4) } \\
\text { Process Impacts Study (Path Forward for } \\
\text { Developing Retrieval Performance Evaluation } \\
\text { Criteria, January 6, 1997, Task \#7) } \\
\text { Human Health Impacts Study (Path Forward } \\
\text { for Developing Retrieval Performance } \\
\text { Evaluation Criteria, January 6, 1997, Task \#5 } \\
\text { and HTI RPECA Work Plan, Jacobs } \\
\text { Engineering Group Inc, Febraury 1997, Task } \\
\text { 1) } \\
\text { Long-Term Risk Study (Path Forward for } \\
\text { Developing Retrieval Performance Evaluation } \\
\text { Criteria, January 6, 1997, Task \#6 and Hanford } \\
\text { Tanks Initiative Retrieval Performance } \\
\text { Evaluation Criteria Assessment Work Plan, } \\
\text { Jacobs Engineering Group Inc, Febraury 1997) } \\
\text { Modeling Support to Long Term Risk Study } \\
\text { (Path Forward for Developing Retrieval } \\
\text { Performance Evaluation Criteria, January 6, } \\
\text { 1997, Task \#10) } \\
\text { Gonclusions and Recommendations (Path } \\
\text { Forward for Developing Retrieval Performance } \\
\text { Evaluation Criteria, January 6, 1997, Task \#12 } \\
\text { and HTI RPECA Work Plan, Jacobs } \\
\text { Engineering Group Inc, Febraury 1997, Task } \\
\text { 5) } \\
\quad \text {. . }\end{array}$ \\
\hline
\end{tabular}




\begin{tabular}{|c|c|c|c|}
\hline Closure Basis Decisions & Decision Criteria & information Needs & Studies Planned \\
\hline $\begin{array}{l}\text { Surface Barriers } \\
\text { - Use RCRA surface barriers } \\
\text { - Use Hanford surface barriers } \\
\text { - Use no surface barriers }\end{array}$ & $\begin{array}{l}\text { Does it meet TPA Requirements? } \\
\text { - i.a.w. WAC } 173-303-610 \\
\text { - Cost } \\
\text { - Potential worker exposure to radiation } \\
\text { - Schedule requirements } \\
\text { Does it meet Regulatory } \\
\text { Requirements? }\end{array}$ & \begin{tabular}{|l|} 
\#13) Surface Barrier \\
Alternatives \\
- Cost vs. efficiency \\
- Effect on transport of sub- \\
surface Waste \\
\#6) Compliance Assessment \\
- Performed for each surface \\
barrier alternative \\
- Which surface barrier will meet \\
all regulatory requirements.
\end{tabular} & $\begin{array}{l}\text { Compliance Assessment Study (Path } \\
\text { Forward for Developing Retrieval Performance } \\
\text { Evaluation Criteria, January 6, 1997, Task \#9 } \\
\text { and HTI RPECA Work Plan, Jacobs } \\
\text { Engineering Group Inc, Febraury 1997, Task } \\
\text { 3) }\end{array}$ \\
\hline & Satisfies Public Concerns and Values? & $\begin{array}{l}\text { \#8) Stakeholder Involvement } \\
\text { - Stakeholders will be asked to } \\
\text { provide input on barrier selection. }\end{array}$ & $\begin{array}{l}\text { Stakeholder Involvement (Path Forward for } \\
\text { Developing Retrieval Performance Evaluation } \\
\text { Criteria, January 6, 1997, Task \#11; Tanks } \\
\text { Initiative Retrieval Performance Evaluation } \\
\text { Criteria Assessment Work Plan, Jacobs } \\
\text { Engineering Group Inc, Febraury 1997, Task } 4 \\
\text { DQO for Implementation of MOU (Path } \\
\text { Forward for Developing Retrieval Performance } \\
\text { Evaluation Criteria, January 6, 1997, Task \#1) }\end{array}$ \\
\hline • & $\begin{array}{l}\text { Provides for Public Safety? } \\
\text { - Subsurface transport } \\
\text { - Future generations not aware of } \\
\text { Hanford } \\
\text { - Water table contamination } \\
\text { - Air transport } \\
\text { Protects the Environment? } \\
\text { - Columbia River } \\
\text { - Aquifer } \\
\text { - Hanford Soils } \\
\text { - Hanford Wildlife and Biosphere } \\
\text { Provides for Worker Safety? } \\
\text { - During retrieval and treatment } \\
\text { - During monitoring activities } \\
\text { - }\end{array}$ & $\begin{array}{l}\text { \#9) Human Health and Safety; } \\
\text { \#10) Long Term Risk Study; and } \\
\text { \#11) Environmental Effects } \\
\text { - Transport modeling } \\
\text { - Process system impacts } \\
\text { - Performed for each alternative } \\
\text { - Requires waste } \\
\text { characterization and inventory } \\
\text { - Environmental consequences } \\
\text { - Worker safety } \\
\text { - Risk to public } \\
\text { - Programmatic risk } \\
\text { - Industrial Risks } \\
\text { - Performed for each alternative } \\
\end{array}$ & $\begin{array}{l}\text { Waste Inventory Study (Path Fonward for } \\
\text { Developing Retrieval Performance Evaluation } \\
\text { Criteria, January 6, 1997, Task \#4) } \\
\text { Human Health Impacts Study (Path Forward } \\
\text { for Developing Retrieval Performance } \\
\text { Evaluation Criteria, January 6, 1997, Task \#5 } \\
\text { and HTI RPECA Work Plan, Jacobs } \\
\text { Engineering Group Inc, Febraury 1997, Task } \\
\text { 1) } \\
\text { Long-Term Risk Study (Path Forward for } \\
\text { Developing Retrieval Performance Evaluation } \\
\text { Criteria, January 6, 1997, Task \#6 and Hanford } \\
\text { Tanks Initiative Retrieval Periormance } \\
\text { Evaluation Criteria Assessment Work Plan, } \\
\text { Jacobs Engineering Group Inc, Febraury 1997) } \\
\text { Modeling Support to Long Term Risk Study } \\
\text { (Path Forward for Developing Retrieval } \\
\text { Performance Evaluation Criteria, January 6, } \\
\text { 1997, Task \#10) } \\
\text { Conclusions and Recommendations (Path } \\
\text { Forward for Developing Retrieval Performance } \\
\text { Evaluation Criteria, January 6, 1997, Task \#12 } \\
\text { and HTI RPECA Work Plan, Jacobs } \\
\text { Engineering Group inc, Febraury 1997, Task } \\
\text { 5) }\end{array}$ \\
\hline
\end{tabular}




\begin{tabular}{|c|c|c|c|}
\hline Closure Basis Decisions & Decision Criteria & Information Needs & Studies Planned \\
\hline \multirow[t]{3}{*}{$\begin{array}{l}\text { Sub-Surface Barriers } \\
\text { - No sub-surface barriers } \\
\text { - Sub-surface barriers on some tanks } \\
\text { - Sub-surface barriers on all tanks }\end{array}$} & $\begin{array}{l}\text { Does it meet TPA Requirements? } \\
\text { - i.a.w. WAC 173-303-610 } \\
\text { - Cost } \\
\text { - Technical practicability } \\
\text { - previously demonstrated? } \\
\text { - Worker exposure during placement } \\
\text { - Schedule requirements } \\
\text { Does it meet Regulatory } \\
\text { Requirements? }\end{array}$ & $\begin{array}{l}\text { \#14) Sub-Surface Barrier Study } \\
\text { - Cost vs. efficiency for each } \\
\text { - Compare each sub-surface } \\
\text { barrier with relevant regulatory } \\
\text { requirements } \\
\text { - Worker exposure in placing the } \\
\text { barriers } \\
\text { \#6) Compliance Assessment } \\
\text { - Performed for each sub-surface } \\
\text { barrier alternative } \\
\text { - is there any regulatory } \\
\text { requirement for sub-surface } \\
\text { barriers? }\end{array}$ & $\begin{array}{l}\text { IBD }==\text { What studk determined that subz } \\
\text { surface barriers would not be used??? } \\
\\
\text { Compliance Assessment Study (Path } \\
\text { Fonward for Developing Retrieval Performance } \\
\text { Evaluation Criteria, January } 6,1997 \text {, Task } \# 9 \\
\text { and HTI RPECA Work Plan, Jacobs } \\
\text { Engineering Group Inc, Febraury 1997, Task } \\
\text { 3) }\end{array}$ \\
\hline & Satisfies Public Concerns and Values? & $\begin{array}{l}\text { \#8) Stakeholder Involvement } \\
\text { - After the technical facts are } \\
\text { assembled, the stakeholders will } \\
\text { be informed of the alternatives and } \\
\text { their opinion will be solicited. }\end{array}$ & $\begin{array}{l}\text { Stakeholder Involvement (Path Forward for } \\
\text { Developing Retrieval Performance Evaluation } \\
\text { Criteria, January 6, 1997, Task \#11; Tanks } \\
\text { Initiative Retrieval Performance Evaluation } \\
\text { Criteria Assessment Work Plan, Jacobs } \\
\text { Engineering Group Inc, Febraury 1997, Task } 4 \\
\text { DQO for Implementation of MOU (Path } \\
\text { Fonward for Developing Retrieval Performance } \\
\text { Evaluation Criteria, January 6, 1997, Task \#1) }\end{array}$ \\
\hline & \begin{tabular}{|l} 
Provides for Public Safety? \\
- Subsurface transport \\
- Future generations not aware of \\
Hanford \\
- Water table contamination \\
Protects the Environment? \\
- Columbia River \\
- Aquifer \\
- Hanford Soils \\
- Hantord Wildlife and Biosphere \\
- During placement of barrier \\
- During monitoring activities \\
During retrieval \\
-
\end{tabular} & $\begin{array}{l}\text { \#9) Human Health and Safety; } \\
\text { \#10) Long Term Risk Study; and } \\
\# 11) \text { Environmental Effects } \\
\text { - Transport modeling effects for } \\
\text { each sub-surface barrier } \\
\text { - Process system impacts } \\
\text { - Performed for each sub-surface } \\
\text { barrier alternative } \\
\text { - Requires waste } \\
\text { characterization and inventory } \\
\text { - Environmental consequences } \\
\text { - Worker safety } \\
\text { - Risk to public } \\
\text { - Programmatic risk } \\
\text { - Industrial Risks } \\
\text { - Risks from hazardous materials } \\
\text { - Risks from radioactive materials } \\
\text { - Performed for each set of } \\
\text { alternatives } \\
\text { Waste Inventory study }\end{array}$ & $\begin{array}{l}\text { Waste Inventory Study (Path Forward for } \\
\text { Developing Retrieval Performance Evaluation } \\
\text { Criteria, January 6, 1997, Task \#4) } \\
\text { Human Health Impacts Study (Path Forward } \\
\text { for Developing Retrieval Performance } \\
\text { Evaluation Criteria, January 6, 1997, Task \#5 } \\
\text { and HTI RPECA Work Plan, Jacobs } \\
\text { Engineering Group Inc, Febraury 1997, Task } \\
\text { 1) } \\
\text { Long-Term Risk Study (Path Forward for } \\
\text { Developing Retrieval Performance Evaluation } \\
\text { Criteria, January 6, 1997, Task \#6 and Hanford } \\
\text { Tanks Initiative Retrieval Performance } \\
\text { Evaluation Criteria Assessment Work Plan, } \\
\text { Jacobs Engineering Group Inc, Febraury 1997) } \\
\text { Modeling Support to Long Term Risk Study } \\
\text { (Path Forward for Developing Retrieval } \\
\text { Performance Evaluation Criteria, January 6, } \\
\text { 1997, Task \#10) } \\
\text { Conclusions and Recommendations (Path } \\
\text { Forward for Developing Retrieval Performance } \\
\text { Evaluation Criteria, January 6, 1997, Task \#12 } \\
\text { and HTI RPECA Work Plan, Jacobs } \\
\text { Engineering Group Inc, Febraury 1997, Task } \\
5 \text { ) }\end{array}$ \\
\hline
\end{tabular}


HNF-SD-HTI-TX-001

Revision 0

APPENDIX B

EVALUATION OF INFORMATION NEEDS

B-1 
HNF-SD-HTI-TX-001

Revision 0

This page intentionally left blank. 


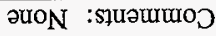

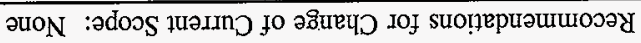

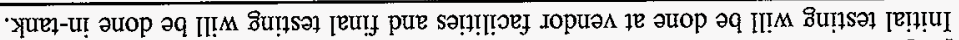

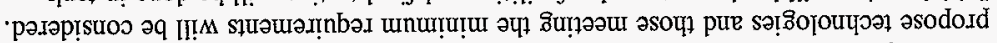

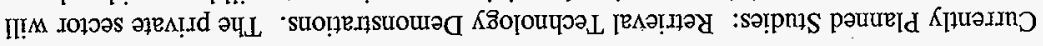

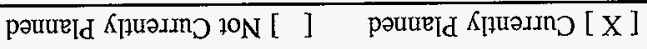

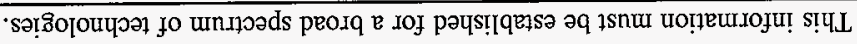

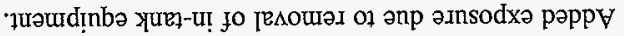

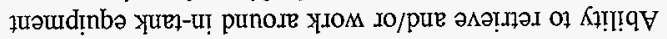

səzeI uopjonpord

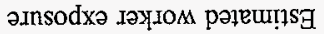

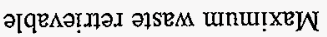

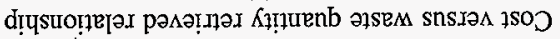

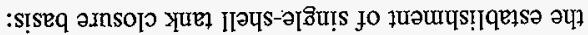

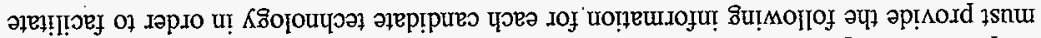

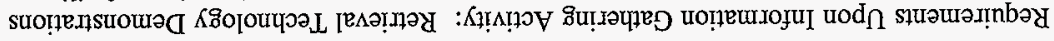

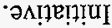

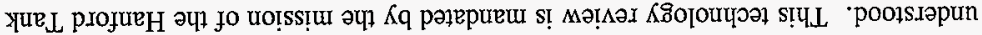

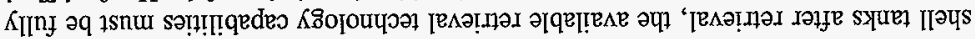

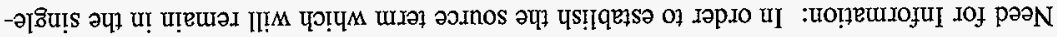

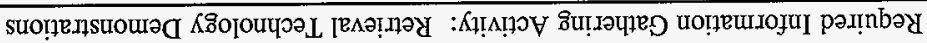

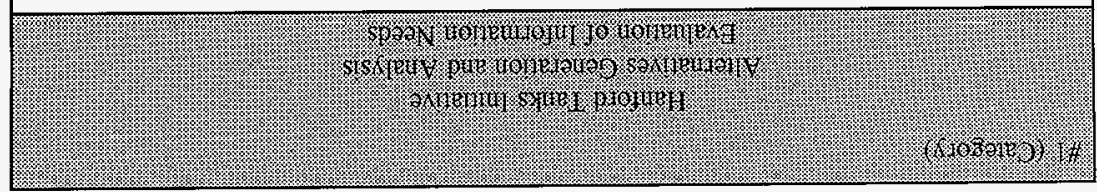

0 Uоำ!

I00-XL-ILH- $G S^{-}$- INH 
วUON :słuəuturoj

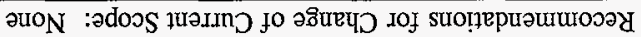

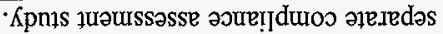

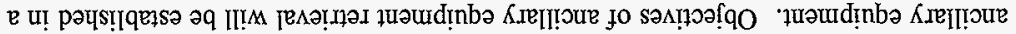
әप1 8ินฺ

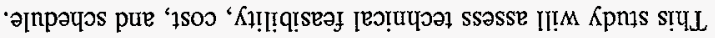

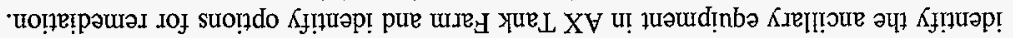

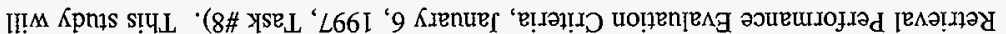

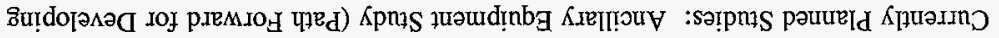

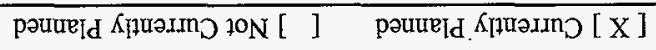

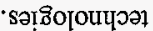

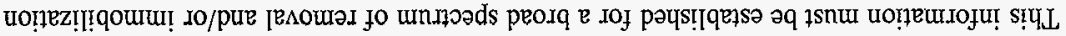

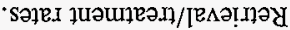

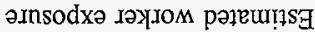

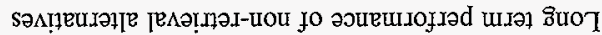

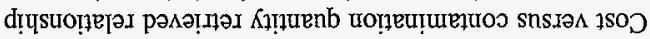

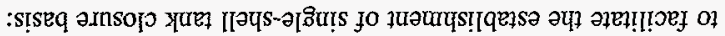

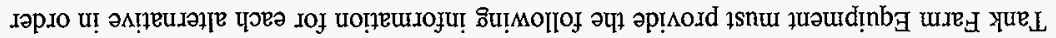

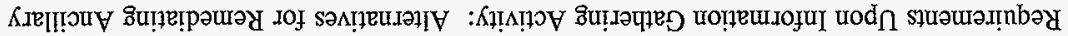

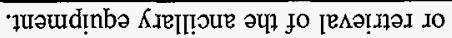

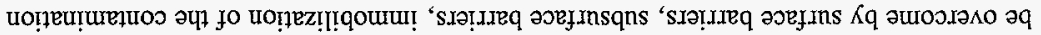

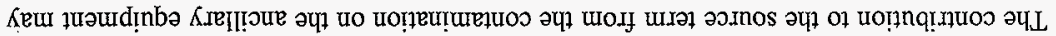
' quәưoI!

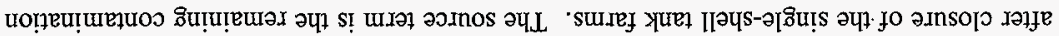
"uirə] ә0.Inos

१uəưdịnbag ưre⿻

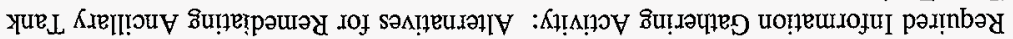

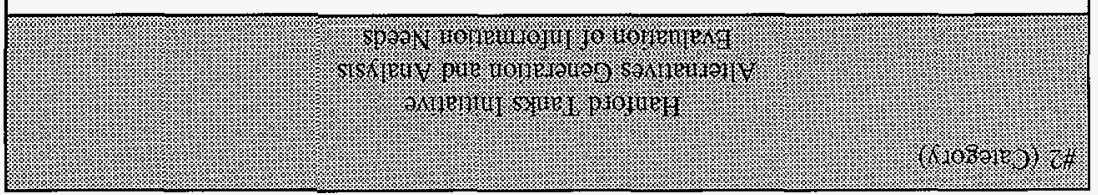


วtroN :squวuruop

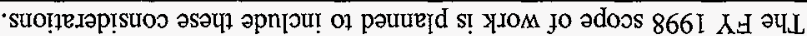

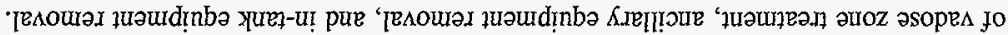

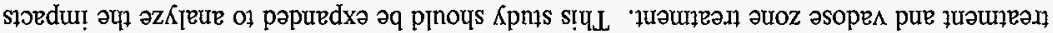

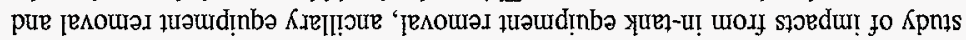

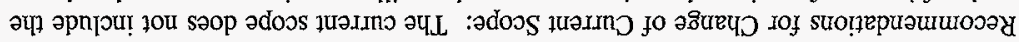

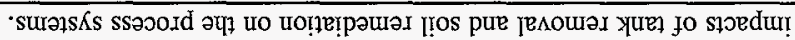

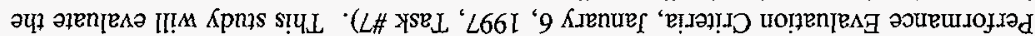
[e

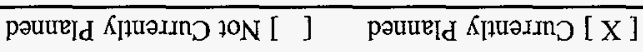

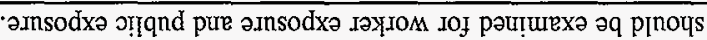

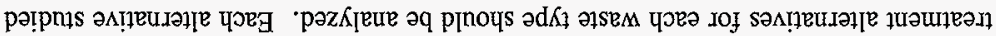

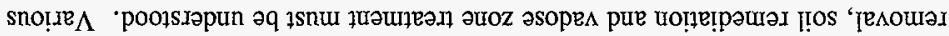

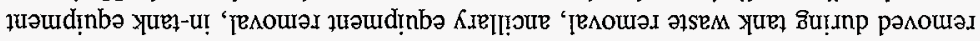

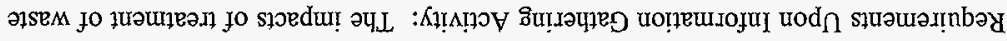

's[etroneut

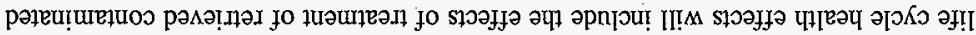

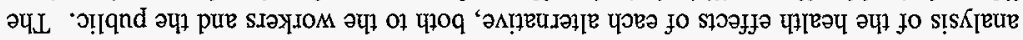

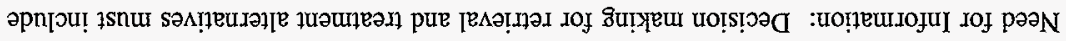

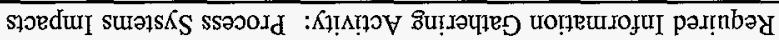

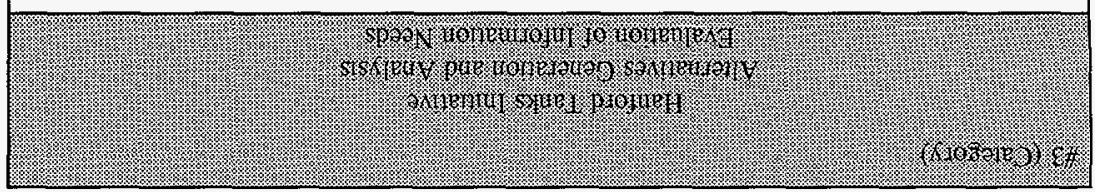

0 uots!aəy

I00-XI-ILH-GS-INH 


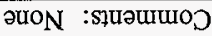

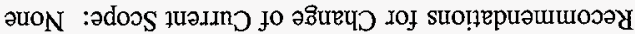

'әүпрәчоs pue '

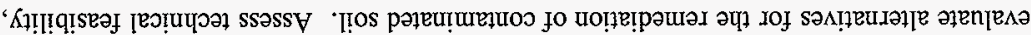

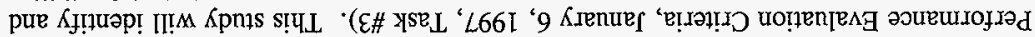

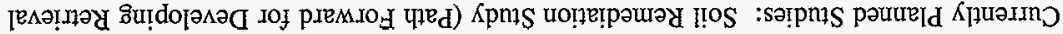

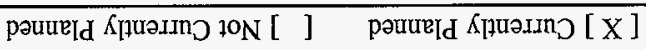

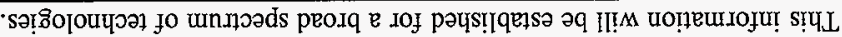

-səjer uononpord

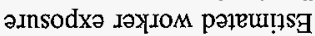

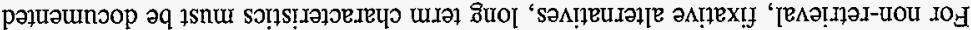

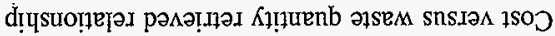

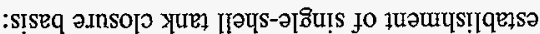

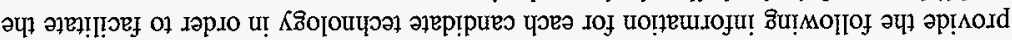

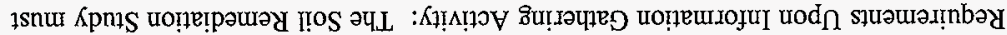

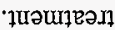

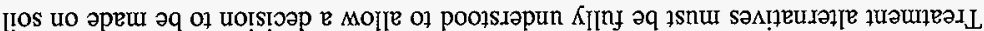

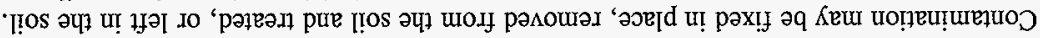

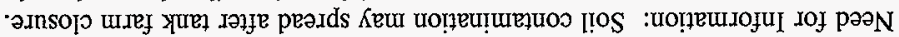

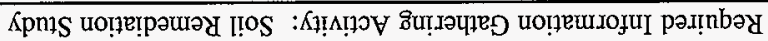

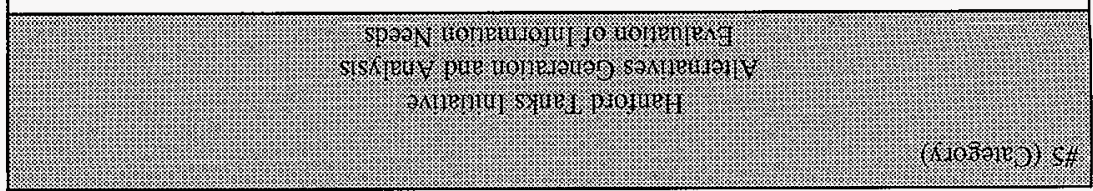

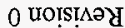

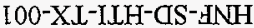




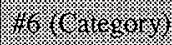

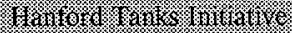

.6.

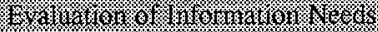

Required Information Gathering Activity: Compliance Assessment Study

Need for Information: Final closure of the single-shell tank farms will be in accordance with applicable regulatory requirements and the Tri-Party Agreement. A Compliance Assessment Study will determine the applicable regulatory requirements and recommend a process to comply with the process outlined in the Tri-Party Agreement for all elements in the tank farm operable units.

Requirements Upon Information Gathering Activity: The closure of a tank farm operable unit is composed of the following elements:

- Waste retrieval and/or treatment

- In-tank equipment retrieval and/or treatment

- Ancillary equipment retrieval and/or treatment

- Tank shell and structural material retrieval and/or treatment

- Soil retrieval and/or treatment

- Residual waste treatment

- Vadose zone treatment

- Surface barrier

- Subsurface barrier.

The regulations must be understood for each of these elements as we go into the closure process with the Tri-Party Agreement parties and the other stakeholders.

[X] Currently Planned [ ] Not Currently Planned

Currently Planned Studies: DQO for Implementation of MOU (Path Forward for Developing Retrieval Performance Evaluation Criteria, January 6, 1997, Task \#1); Compliance Assessment Study (Path Forward for Developing Retrieval Performance Evaluation Criteria, January 6, 1997, Task \#9 and HTI RPECA Work Plan, Jacobs Engineering Group, Inc., February 1997, Task \#3). These studies will identify applicable and appropriate requirements and regulations associated with closure alternatives.

Recommendations for Change of Current Scope: None

Comments: The compliance assessment currently planned will assess applicable and appropriate regulatory requirements associated with all major components of each retrieval closure alternative evaluated. 


\begin{tabular}{|c|}
\hline 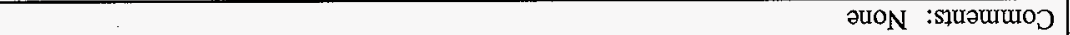 \\
\hline 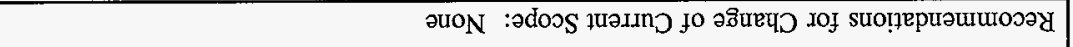 \\
\hline 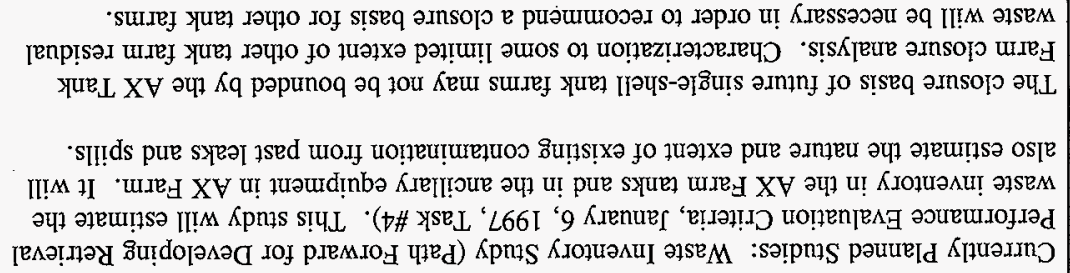 \\
\hline 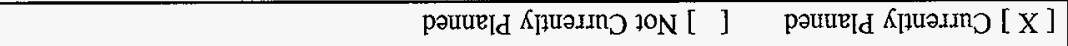 \\
\hline 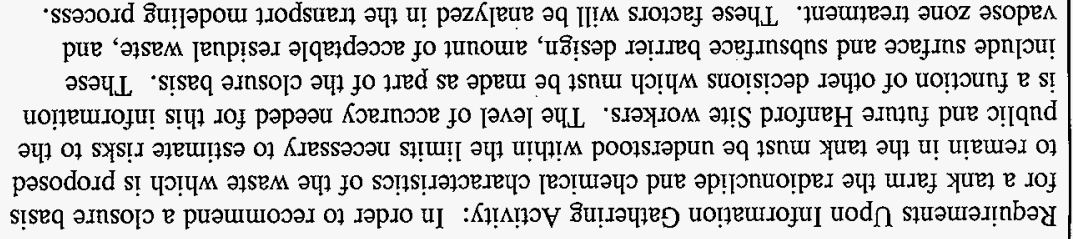 \\
\hline 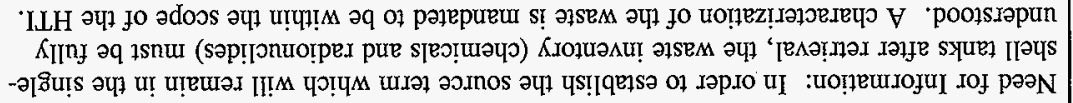 \\
\hline 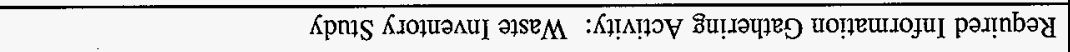 \\
\hline 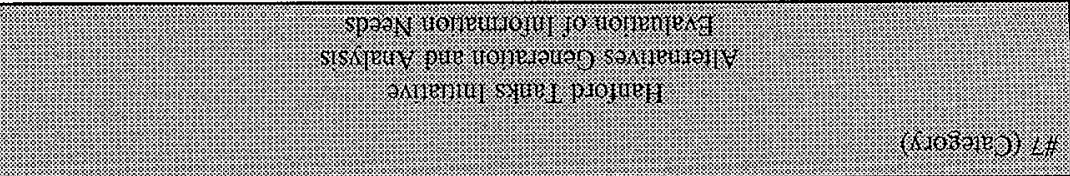 \\
\hline
\end{tabular}




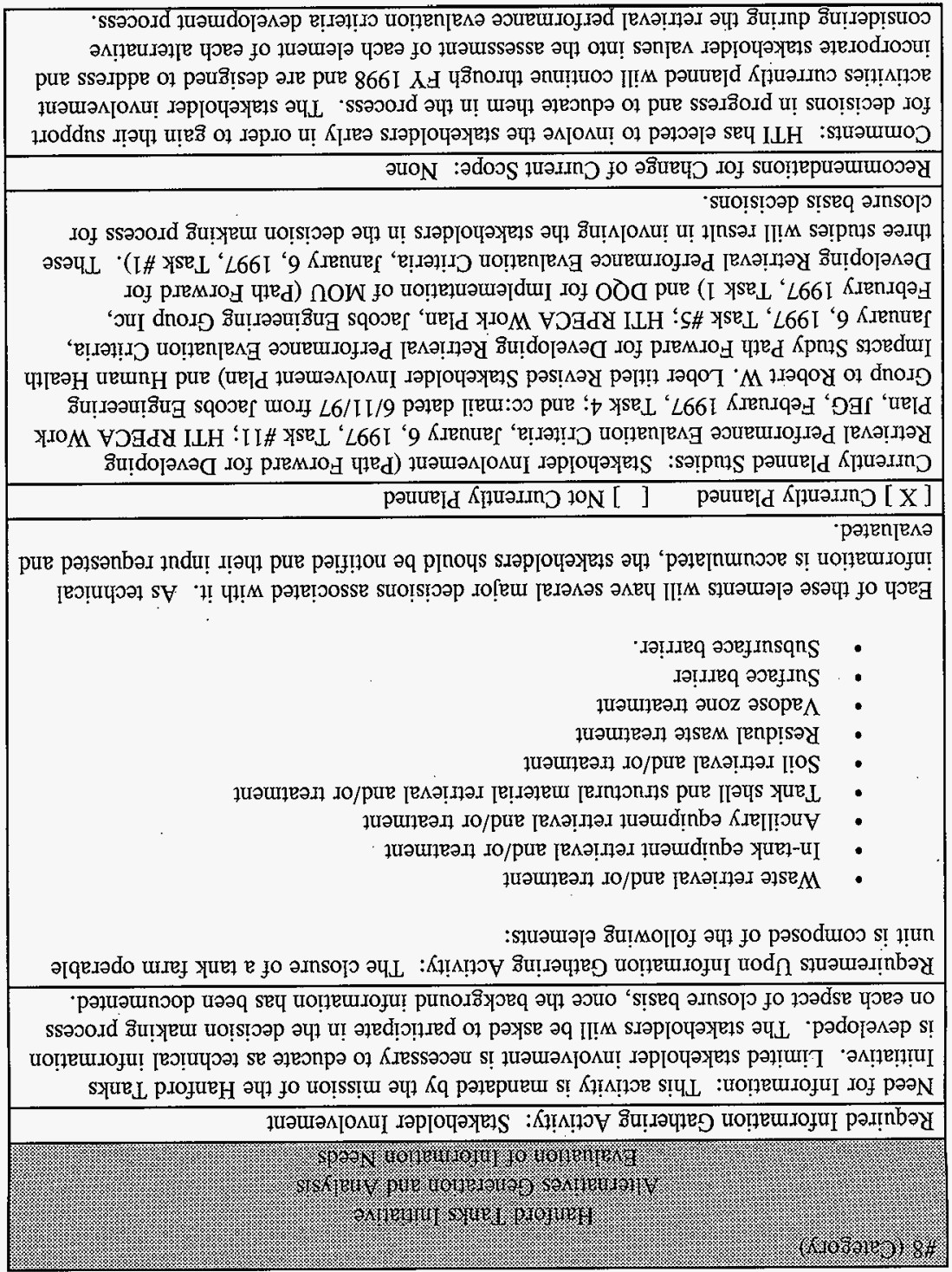




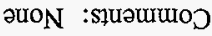

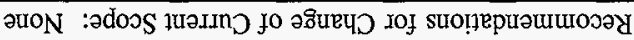

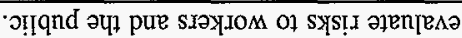

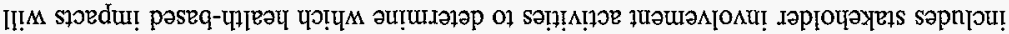

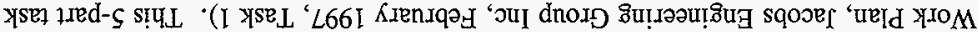

VDAdX ILH pue S\# YSEL 'L66I '9 KIEnuef "

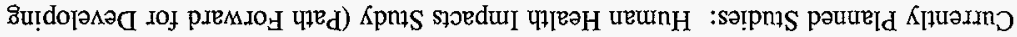

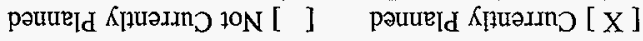

- Kur y! 'spəəu uompunojur jeuol!tppe

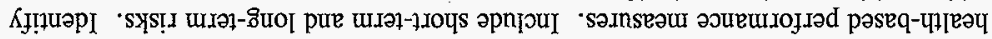

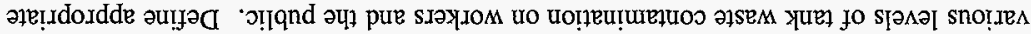

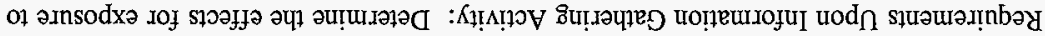

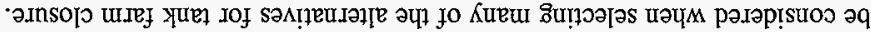

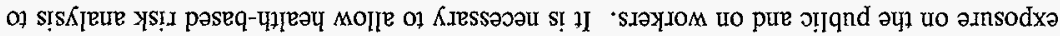

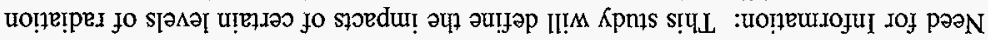

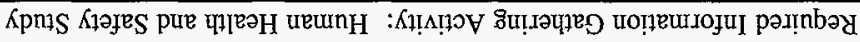

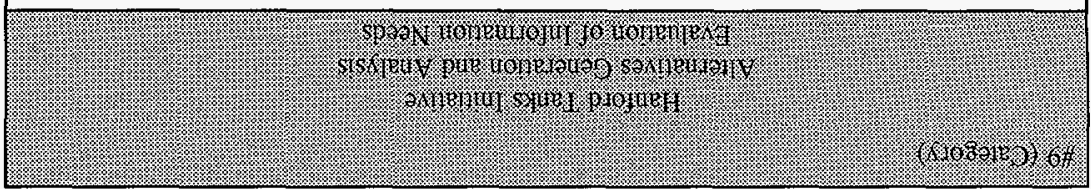

0 UIISTAN

I00-XI-ILH-CIS-HNH 


\section{Revision 0}

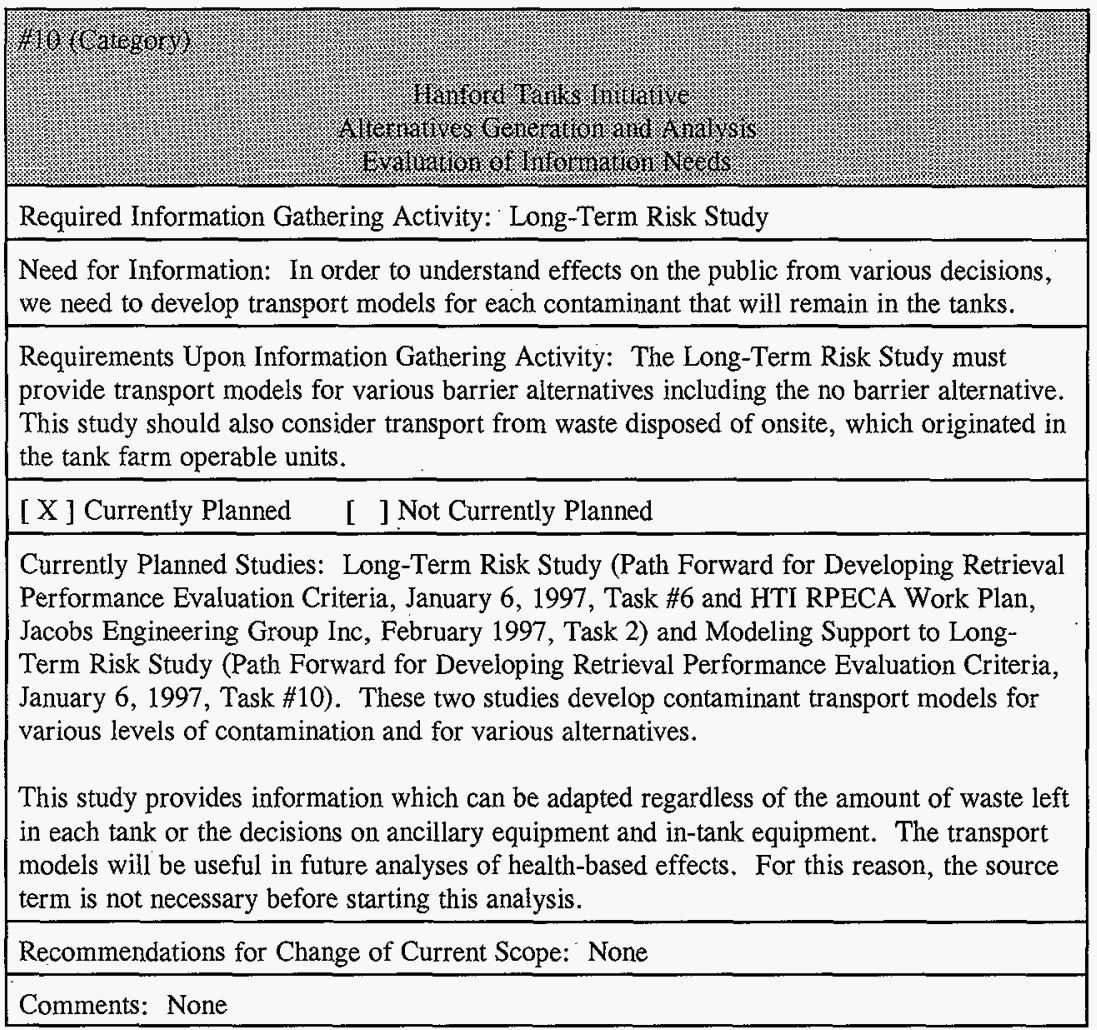




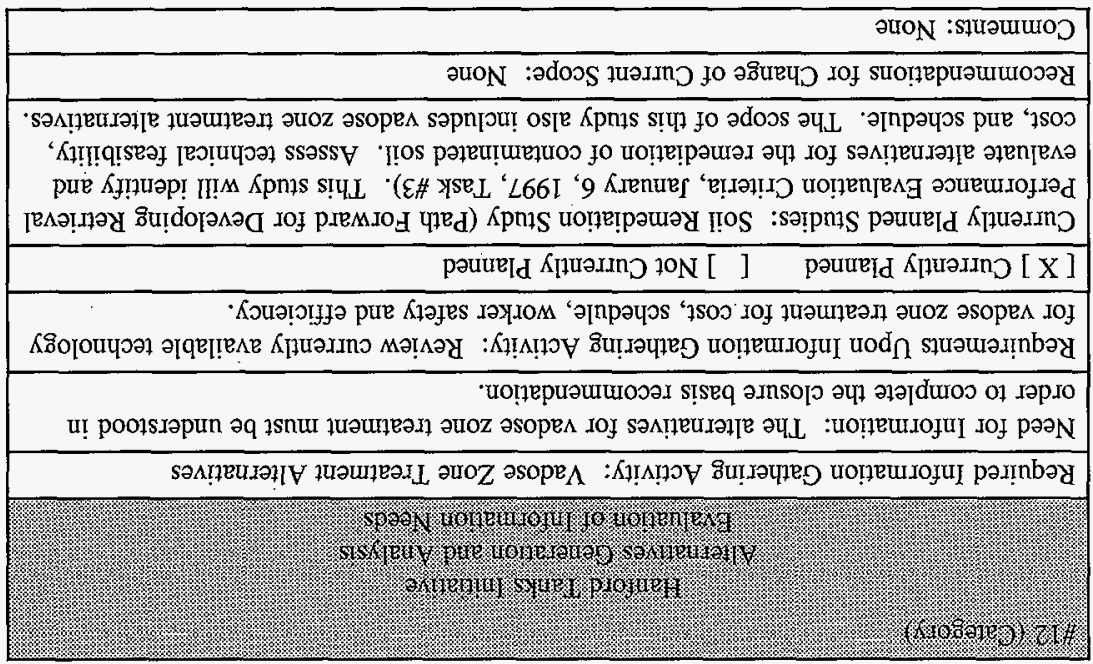

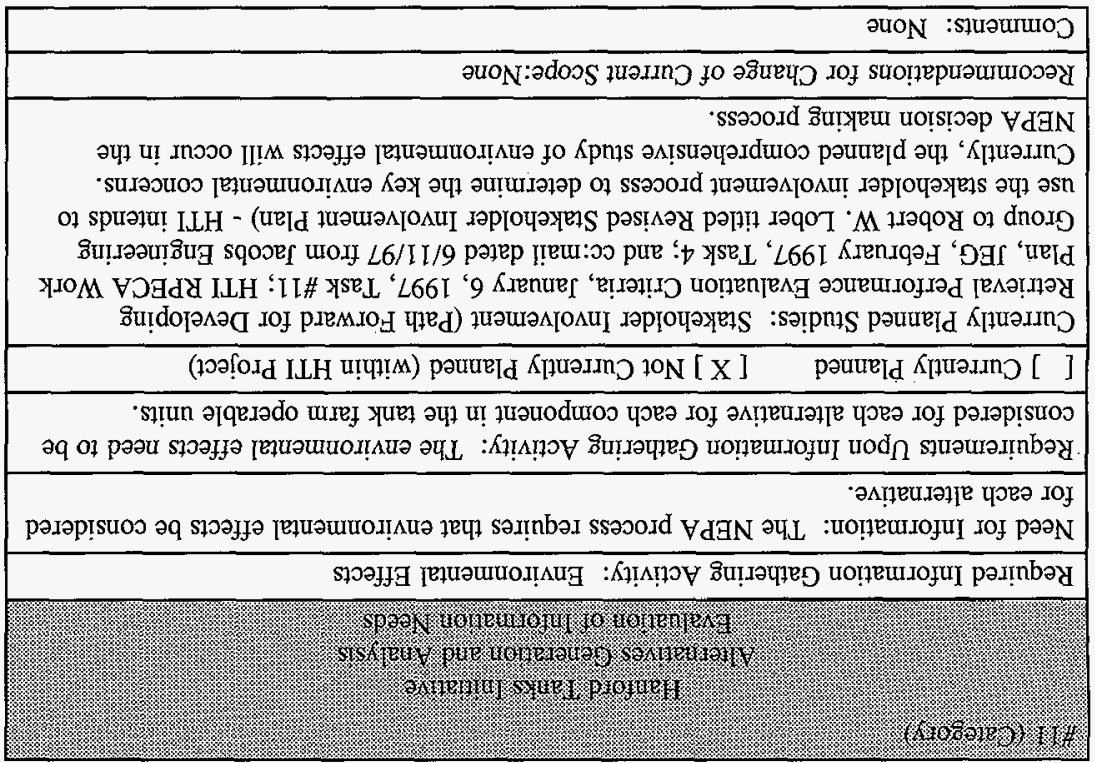




\section{วUION :sIUPUนUOD

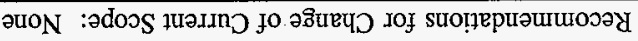

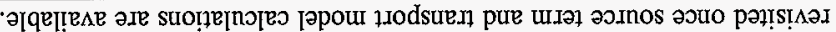

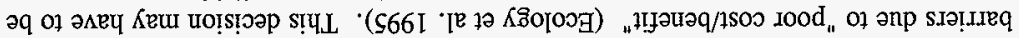

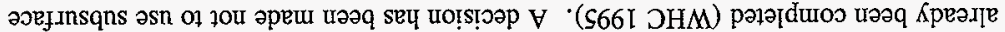

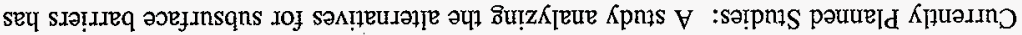

\begin{tabular}{|c|c|}
\hline 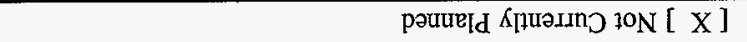 & 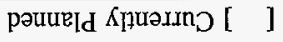 \\
\hline \multicolumn{2}{|c|}{ 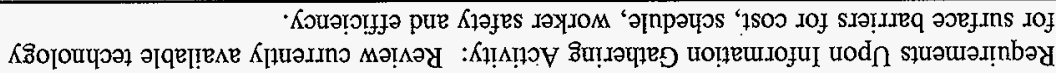 } \\
\hline \multicolumn{2}{|c|}{ 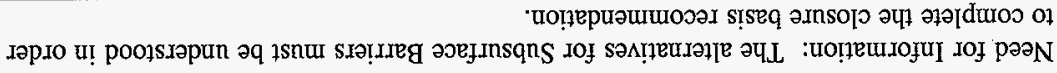 } \\
\hline 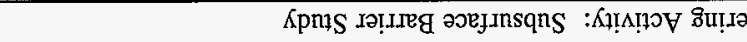 & \\
\hline 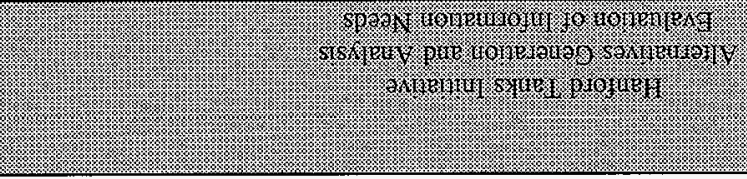 & (1.6. \\
\hline
\end{tabular}

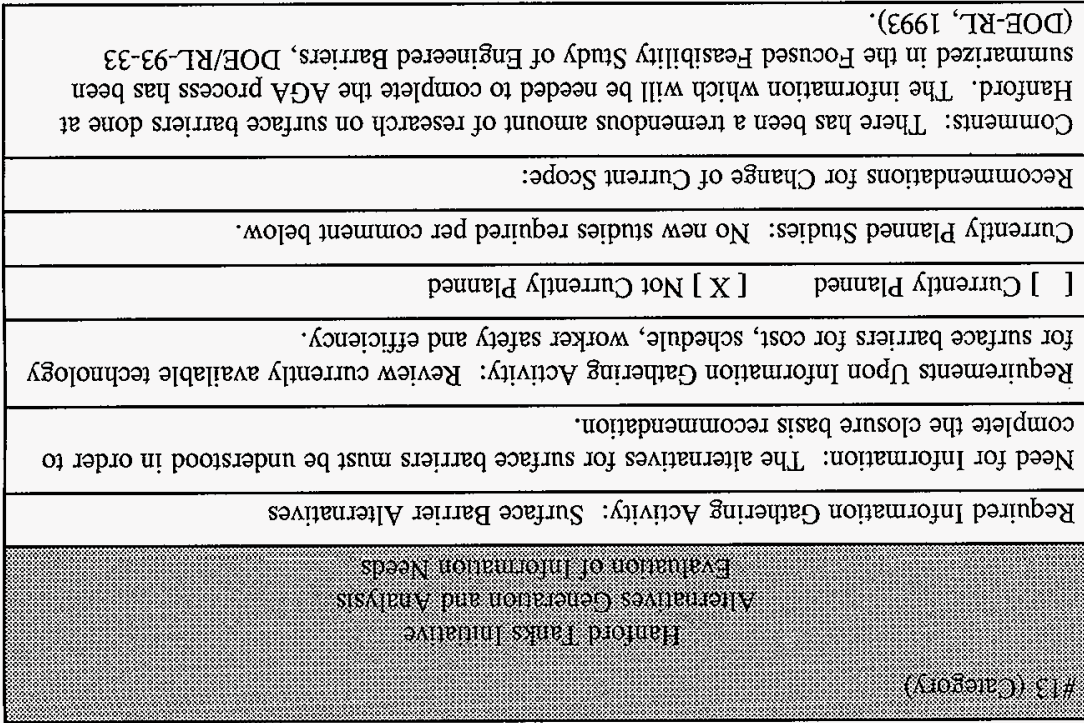




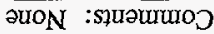

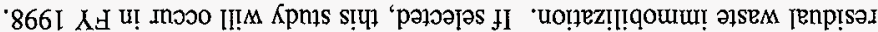

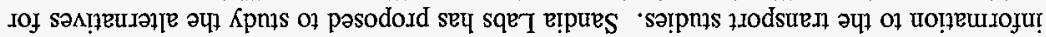

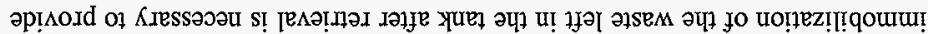

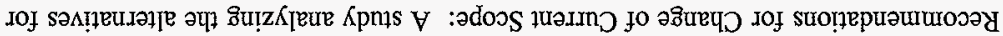

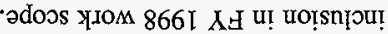

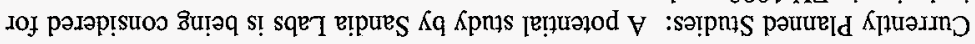

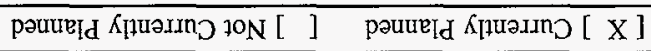

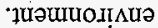

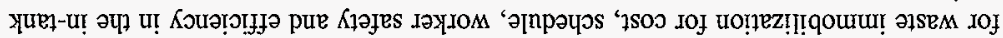

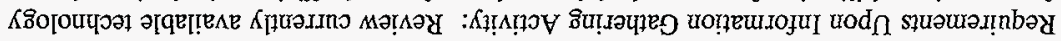

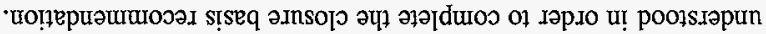

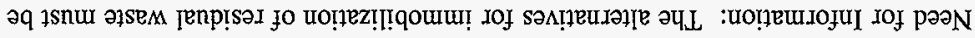
suolpensuouə $\mathrm{a}$

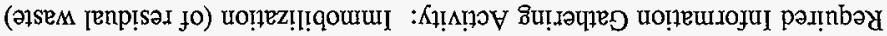

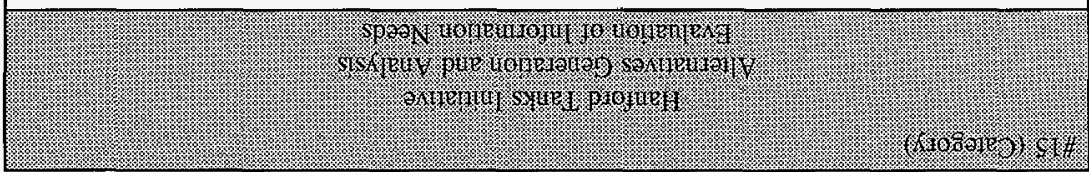




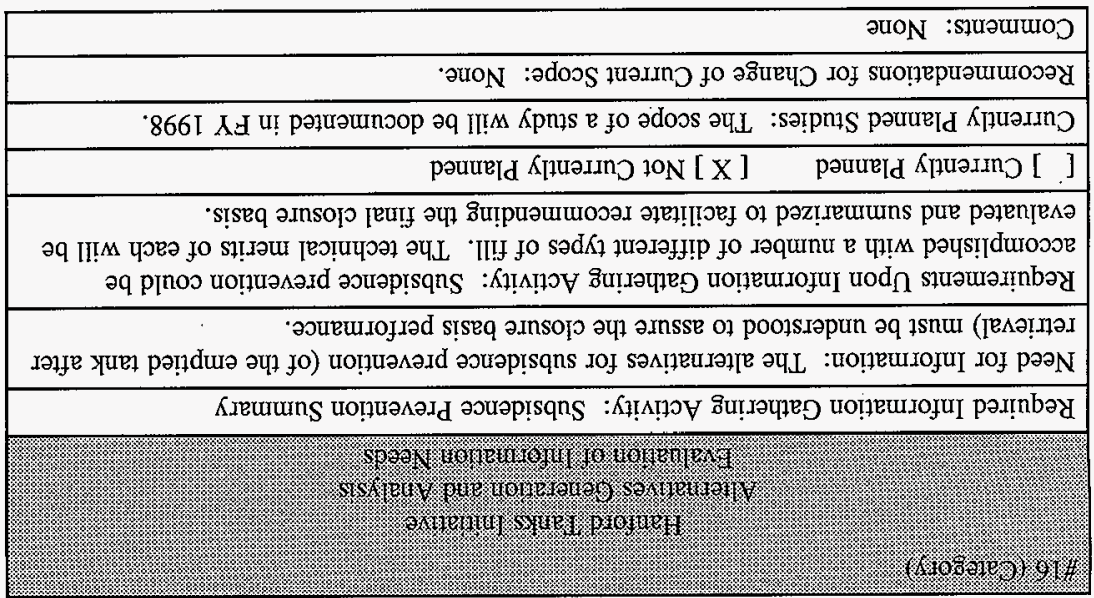




\section{DISTRIBUTION SHEET}

\begin{tabular}{|c|c|c|c|c|c|}
\hline \multirow{2}{*}{$\begin{array}{l}\text { To } \\
\text { Distribution }\end{array}$} & \multirow{2}{*}{\multicolumn{3}{|c|}{$\begin{array}{l}\text { From } \\
\text { P. S. Schaus }\end{array}$}} & \multicolumn{2}{|l|}{ Page 1 of 1} \\
\hline & & & & \multicolumn{2}{|c|}{ Date $10 / 9 / 97$} \\
\hline \multicolumn{4}{|c|}{ Project Title/Work Order } & \multicolumn{2}{|c|}{ EDT No. 622693} \\
\hline \multicolumn{4}{|c|}{$\begin{array}{l}\text { Hanford Tanks Initiative Alternatives Generation and Analysis } \\
\text { Plan for AX Tank Farm Closure Basis, HNF-SD-HTI-TX-001, Rev. O }\end{array}$} & \multicolumn{2}{|l|}{ ECN No. } \\
\hline Name & MSIN & $\begin{array}{l}\text { Text } \\
\text { With All } \\
\text { Attach. }\end{array}$ & Text Only & $\begin{array}{l}\text { Attach./ } \\
\text { Appendix } \\
\text { Only }\end{array}$ & $\begin{array}{l}\text { EDT/ECN } \\
\text { Only }\end{array}$ \\
\hline $\begin{array}{l}\text { Central Files } \\
\text { DOE Reading Room } \\
\text { HTI Project Files (2) }\end{array}$ & $\begin{array}{l}\mathrm{B} 1-07 \\
\mathrm{Al}-65 \\
\mathrm{H} 6-08\end{array}$ & $\begin{array}{l}X \\
X \\
X\end{array}$ & & & \\
\hline $\begin{array}{l}\text { D. L. Becker } \\
\text { J. W. Bloom } \\
\text { E. A. Fredenburg } \\
\text { J. C. Henderson } \\
\text { J. J. Huston } \\
\text { D. A. Myers } \\
\text { M. E. Nelson } \\
\text { R. W. Root } \\
\text { P. S. Schaus (2 copies) } \\
\text { W. A. Skelly }\end{array}$ & $\begin{array}{l}\mathrm{H} 6-12 \\
\mathrm{H} 6-12 \\
\mathrm{H} 6-12 \\
\mathrm{~B} 1-40 \\
\mathrm{H} 5-61 \\
\mathrm{G} 3-21 \\
\mathrm{~B} 1-40 \\
\mathrm{H} 6-12 \\
\mathrm{H} 5-03 \\
\mathrm{H} 5-61\end{array}$ & $\begin{array}{l}x \\
x \\
x \\
x \\
x \\
x \\
x \\
x \\
x \\
x \\
x\end{array}$ & & & \\
\hline $\begin{array}{l}\text { M. J. GTasper (DOE-RL) } \\
\text { J. P. Hanson (DOE-RL) } \\
\text { C. D. West (DOE-RL) }\end{array}$ & $\begin{array}{l}K 8-50 \\
\text { K8-50 } \\
\text { S7-53 }\end{array}$ & $\begin{array}{l}x \\
x \\
x\end{array}$ & & & \\
\hline
\end{tabular}

